WellBeing International

WBI Studies Repository

$11-1984$

\title{
Life History Patterns and the Comparative Social Ecology of Carnivores
}

\author{
Marc Bekoff \\ University of Colorado \\ Thomas J. Daniels \\ University of Colorado \\ John L. Gittleman \\ Smithsonian Institution
}

Follow this and additional works at: https://www.wellbeingintlstudiesrepository.org/acwp_ena

Part of the Animal Studies Commons, Behavior and Ethology Commons, and the Comparative Psychology Commons

\section{Recommended Citation}

Bekoff, M., Daniels, T. J., \& Gittleman, J. L. (1984). Life history patterns and the comparative social ecology of carnivores. Annual review of ecology and systematics, 15, 191-232.

This material is brought to you for free and open access by WellBeing International. It has been accepted for inclusion by an authorized administrator of the WBI Studies Repository. For more information, please contact wbisr-info@wellbeingintl.org.

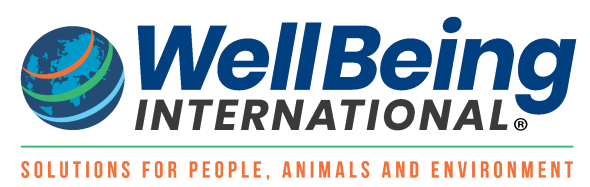




\title{
Life History Patterns and the Comparative Social Ecology of Carnivores
}

\author{
Marc Bekoff ${ }^{1}$, Thomas J. Daniels ${ }^{1}$, John L. Gittleman ${ }^{2}$ \\ ${ }^{1}$ University of Colorado \\ ${ }^{2}$ Smithsonian Institution
}

\section{INTRODUCTION}

The mammalian order Carnivora is characterized by a great range of behavior- al, ecological, and morphological adaptations, as well as substantial intraspecific variability (i.e. behavioral scaling; see 324). For example, in wolves (see Table 1 for scientific names), body size ranges from 31 to $78 \mathrm{~kg}$, litter size varies from 1 to 11, home-range size differs 50-100 fold, populations are found in every vegetational zone except tropical forests and arid deserts, and individuals may live alone, in pairs, or in large packs (124, 204, 332).

Despite such widespread variation, comparative analyses indicate that there also is remarkable consistency $(86,105)$ in the ways many diverse carnivores adapt to their habitats. Therefore, it is possible to highlight trends in the phylogeny of behavior and life history characteristics by drawing on data from numerous disciplines, including anatomy, physiology, taxonomy, behavior, and ecology $(16,54,83,84$, 92, 93, 97, 128, 191, 196, 199, 242, 243, 313, 331).

Due to space limitations, we will primarily review field studies focusing on the variation in behavior, body size, and life histories and emphasize data collected on identified individuals that have been observed directly (sometimes supplemented by radio-tracking) over long periods of time. Such studies are limited in number and comparative breadth, so information from shorter field studies and data on captive animals will also be used as a supplement. Comparisons of artificially and nonartificially fed groups must be treated carefully, however, since food resources have strong direct effects on social behavior (263). In addition, comparisons of exploited and (relatively) unexploited populations must take the food source into account (156). Finally, we will briefly discuss some practical aspects of data collection and analysis.

Our approach is pluralistic in two respects. First, rather than focusing on either intraspecific or interspecific variation, we emphasize the reciprocal exchange of information between both levels of analysis. Comparative studies generate hypotheses that often can only be verified in single-species studies, and the generality of functional explanations of a species' trait rests with comparative analyses among related taxa. Second, because confounding variables involving size constraints and phylogenetic effects are frequently associated with behavioral and ecological diversity $(62,64,112,113 a)$, we include allometric and phylogenetic trends in our discussion of carnivore behavioral ecology.

Both descriptive studies and field experiments are still sorely needed for most carnivores. Textbooks, reviews, and popular articles frequently exaggerate our knowledge of certain phenomena (71). As Dunbar (75) stressed, long-term field studies must be performed if we are ever to learn about the evolution of the behavior and social ecology of long-lived "higher" species, in which intraspecific variation is so obvious. 
Table 1. Scientific and common names of Carnivores referred to in the text.

\begin{tabular}{|c|c|c|c|}
\hline \multicolumn{2}{|l|}{ Family } & \multicolumn{2}{|l|}{ Family } \\
\hline Canidae & & Viverridae & \\
\hline Dusicyon culpaeus & South American fox (culpeo) & Helogale parvula & Dwarf mongoose \\
\hline Dusicyon griseus & Chico gray fox & Suricata suricatta & Meerkat \\
\hline Fennecus zerda & Fennec fox & Hemigalus derbyanus & Banded palm civet \\
\hline Lycaon pictus & African wild dog & Ichneumia albicauda & White-tailed mongoose \\
\hline Otocyon megalotis & Bat-eared fox & Mungos mungo & Banded mongoose \\
\hline Alopex lagopus & Arctic fox & Nandinia binotata & Palm civet \\
\hline Canis lupus & Wolf & Osbornictus piscivorous & Fishing genet \\
\hline Canis latrans & Coyote & Genetta genetta & Common genet \\
\hline Canis aureus & Golden jackal & Fossa fossa & Fanaloka \\
\hline Canis mesomelas & $\begin{array}{l}\text { Black-backed (silverbacked) } \\
\text { jackal }\end{array}$ & & \\
\hline Nyctereutes procvonoides & Raccoon dog & $\underline{\text { Hyaenidae }}$ & \\
\hline Vulpes vulpes & Red fox & Hyaena hyaena & Striped hyena \\
\hline Cuon alpinus & Dhole or red dog & Hyaena brunnea & Brown hyena \\
\hline Cerdocyon thous & Crab-eating fox & Crocuta crocuta & Spotted hyena \\
\hline Speolhos venaticus & Bush dog & Proteles cristatus & Aardwolf \\
\hline \multirow[t]{2}{*}{ Chrysocyon brachyurus } & Maned wolf & & \\
\hline & & Felidae & \\
\hline Procyonidae & & Herpailurus jagouaroundi & Jaguarondi \\
\hline Procyon lotor & Raccoon & Leopardus geoffroyi & Geoffroy's cat \\
\hline \multirow{2}{*}{ Nasua narica } & Coati & Puma concolor & Mountain lion or cougar \\
\hline & & Felis margarita & Sand cat \\
\hline$\underline{\text { Ursidae }}$ & & Prionailurus bengalensis & Bengal cat \\
\hline Ursus americanus & Black bear & Panthera leo & African lion \\
\hline Thalarctos maritimus & Polar bear & Panthera tigris & Tiger \\
\hline \multirow[t]{2}{*}{ Helarctos malavanus } & Malayan sun bear & Panthera pardus & Leopard \\
\hline & & Panthera onca & Jaguar \\
\hline$\underline{\text { Ailuridae }}$ & & Acinonyx jubatus & Cheetah \\
\hline \multirow[t]{2}{*}{ Ailurus fulgens } & Red panda & Leopardus pardalis & Ocelot \\
\hline & & Lynx canadensis & Lynx \\
\hline Ailuropodidae & & Lynx rufus & Bobcat \\
\hline Ailuropoda melanoleuca & Giant panda & Caracal caracal & Caracal \\
\hline \multicolumn{4}{|l|}{ Mustelidae } \\
\hline Mustela nivalis & Least weasel & & \\
\hline Mustela erminea & Stoat or ermine & & \\
\hline Mustela vison & American mink & & \\
\hline Mustela frenata & Long-tailed weasel & & \\
\hline Metes metes & European badger & & \\
\hline Lutra lutra & European otter & & \\
\hline Enhydra lutris & Sea otter & & \\
\hline Martes americana & American marten & & \\
\hline Martes pennanti & Fisher & & \\
\hline Gulo gulo & Wolverine & & \\
\hline Mephitis mephitis & Striped skunk & & \\
\hline
\end{tabular}




\section{GENERAL CHARACTERISTICS OF CARNIVORA}

Broadly speaking, members of the order Carnivora are distinguished from other mammals by their carnassial dentition and the high proportion of vertebrates their diets (Carnivora is derived from the Latin caro: carnis meaning "flesh" and voro, "to devour"). As in other mammalian orders, however, there are many interesting exceptions to these general characteristics. For example, the white-tailed mongoose and the bat-eared fox are insectivorous; the red panda and the giant panda feed primarily on bamboo; and the black bear maintains itself on a catholic herbivorous/frugivorous diet. Besides their dentition and diet, carnivores' other pronounced traits $(93,140,242,243,271)$ include: (a) a jaw joint that is a transverse hinge, which facilitates biting and cutting but does not permit grinding action by the teeth; (b) a vertebral column that is strong and flexible and a long tail; (c) a brain that is relatively large, particularly in comparison to herbivores and insectivores; (d) anal and forehead scent glands that are well-developed and are used in marking, social recognition, and defense; (e) a walking gait that ranges from plantigrade to digitigrade; and (f) in most species, soft fur covered by longer guard hairs.

The order Carnivora is divided into two superfamilies, Canoidea and Feloidea, and seven polytypic families-Canidae, Ursidae, Procyonidae, Mustelidae, Viverridae, Hyaenidae, and Felidae. Although there is continuing controversy, growing evidence suggests that the red panda and giant panda belong in two monotypic families, Ailuridae and Ailuropodidae, respectively, rather than in the Procyonidae or Ursidae, as was previously thought $(83,251)$.

CANIDAE The Canidae, with 36 species divided among 16 genera, is composed of small- to mediumsized carnivores (1-60 kg) distinguished by their cursorial mobility and strong jaws and cheek muscles $(60,226,227,285)$. Canids live in a wide variety of habitats. More behavioral and ecological information is available for Canidae than for any other carnivore family because they are typically diurnal and include an unusually large number of group-living species $(4,16,24,97,105,124,157,159,191,204,331,332)$. In many of these species, both parents provision and protect their young (158). Much of our discussion below centers on patterns in the Canidae.

PROCYONIDAE Closely related to Canidae is Procyonidae, which includes 18 species in 6 genera. Procyonids are comparatively small carnivores $(0.8-12 \mathrm{~kg})$ confined to the New World, and all are semiarboreal, prefer temperate and tropical vegetational zones (144), and have a plantigrade gait. Most of them are solitary, although raccoons are frequently seen in extended family groups (102; Seidensticker, personal communication) and coatis live in female-banded groups with as many as 10 adults $(143,266,267)$.

AILURIDAE AND AILUROPODIDAE Both red pandas and giant pandas (placed in Ailuridae and Ailuropodidae, respectively) are from central Chinese provinces; red pandas also occur in Nepal, Sikkim, and northern Burma. These two species feed primarily on bamboo and are solitary except during the breeding season $(155,251)$.

URSIDAE The family Ursidae (bears) consists of 7 species divided among 6 genera, which (with the exception of the Malayan sun bear) inhabit the Northern Hemisphere and northern South America. Their dentition reflects a shift away from carnivory toward herbivory: The anterior premolars are small and the carnassials are nonsectorial and have lost most of their shearing character. Ursids' walking gait is plantigrade. They are relatively solitary; adults only remain together during breeding or when food is abundant in patches. Maternal care may last for an extended length of time during harsh seasons (93, $129,130)$, which, combined with small litter sizes and long interbirth intervals, results in comparatively low reproductive rates. 
MUSTELIDAE The last family included in the superfamily Canoidea is Mustelidae. It is divided into the following subfamilies: Mustelinae (weasels, polecats, fisher, martens, wolverine, tayra), Mellivorinae (badgers), Mephitinae (skunks), and Lutrinae (otters). Mustelidae consists of 67 species in all, distributed among 27 genera, and they are found everywhere except Australia, Antarctica, and Madagascar. Mustelids are small- to medium-sized carnivores $(.025--45 \mathrm{~kg})$ with long bodies, short legs, and usually medium to long tails. The aquatic Lutrinae and the omnivorous Mephitinae and Mellivorinae are recent radiations that diverged from the basic carnivorous characteristics of the family. Most species are solitary and live in forest habitats $(89,90,296)$, although group living is found in European badgers $(164,165)$ and sea otters (147). Most species in this large family have only been studied in captivity.

VIVERRIDAE The oldest lineage within the superfamily Feloidea is Viverridae. This family has retained many of the features thought to be representative of ancestral carnivores (Miacidae). The Viverridae is the largest carnivore family, is comprised of 70 species distributed among 39 genera, and is confined to the Old World tropics and subtropics. It has six subfamilies: Viverrinae (civets, genets, linsangs), Paradoxurinae (palm civets, binturong), Hemigalinae (fanaloka, banded palm civet), Galadinae (Madagascar mongooses), Herpestinae (mongooses, suricate), and Cryptoprocinae (fossa). Viverrids are small carnivores (0.45-14 kg) and generally have long tails and relatively short limbs that are semiplantigrade or digitigrade (the claws are partly retractile in digitigrade species). The family is a somewhat heterogeneous assemblage and is more ecologically diverse than any other carnivore group, ranging from solitary, forest-living species (common genet) to open savannah, group-living animals (banded and dwarf mongooses). Their dietetic affinities vary from insectivorous (banded palm civets) to frugivorous (palm civet) to piscivorous (fishing genet). Viverridae have not been studied in as much detail as other families $(2,110,135,152,316)$.

HYAENIDAE The family Hyaenidae contains three species of hyenas (in two genera) and the aardwolf. Hyenas are found in Africa, the Middle East, and central and south Asia; aardwolves live in southern Africa. Hyenas are fairly large animals $(8-70 \mathrm{~kg}$ ) with particularly large heads and powerful jaw and neck muscles. Their teeth are large and the carnassials are well developed. Their forequarters are heavier than their hindquarters, their legs are thick, and they have a digitigrade gait. Behaviorally and ecologically, the hyenas are diverse $(212,213,216,230)$. The striped hyena is omnivorous, foraging on fruits, insects, and small mammals (as well as scavenging); it lives in acacia savannah and open grassland habitats (163, 250). Brown hyenas are also omnivorous and live in small family groups of 4 to 14 individuals in open shrub or woodland savannah habitats $(213-216,229,232)$. The spotted hyena is strictly carnivorous, with larger carnassials than the other hyenas, and it lives in "clans" of up to 80 individuals in Ngorongoro Crater or in temporary associations in the Serengeti $(161,162)$. The aardwolf is different from the hyenas, though it is sometimes confused with the striped hyena because of its similar appearance. It has a reduced dentition and a small head and shoulders, feeds mainly on termites, and is solitary (166).

FELIDAE The last carnivore family, Felidae (cats, caracal, puma, ocelot, jaguarondi, lynx, leopard, jaguar, lion, cheetah), contains 37 species and 21 genera. The classification of Felidae remains somewhat uncertain, particularly with regard to the genera Felis and Panthera (227). We have adopted Ewer's taxonomic scheme (93). Felidae are found on all continents except Australia. They are small- to largesized carnivores (1.5-300 kg), short faced, with highly sectorial carnassials and sharp retractile claws (except for cheetahs). The tongue is covered with curved, backwardly directed, horny papillae. Felids are highly carnivorous, and although they are found in every type of habitat, they most often reside in woodland and fringe-woodland terrain. All felids are solitary (157), except for lions, which live in prides of 2 to 18 adult females (usually related to one another) and 1 to 7 adult males (32, 33, 37, 50, 87, 157, 182, 273). In the central Kalahari, female pride mates are frequently unrelated; prides periodically disband and some females join "foreign" prides, especially when prey densities are low (M. J. Owens, personal 
communication). Male breeding coalitions appear to contain nonrelatives more frequently than was previously thought (234); males are typically unrelated to pride females. [Comparative data can be found in Eaton (77-80).]

\section{LIFE HISTORY PATTERNS}

\section{Interspecific Comparisons}

Cross-species comparisons of life history traits in Carnivora reveal extensive differences in rates and modes of reproduction. Undoubtedly, much of this variation may be accounted for by body size differences $(83,319)$, and such allometric effects must be incorporated into comparative studies. Even taxonomically related and similarly sized species differ markedly, however. In the Viverridae, the fanaloka and common genet both weigh an average of $1.7 \mathrm{~kg}$, but their life histories are quite different. The fanaloka's gestation period is about 85 days, it usually has a litter size of one, and it weans its young about 52 days after birth $(1,2,316)$, whereas the common genet's gestation period is about 72 days, its litter size is $3-4$, and it weans its young around 175 days after birth $(93,253,308,316)$.

Because of the great variation within the order, carnivores are an excellent group for studying the adaptive patterns of life history traits. Furthermore, although some variables are difficult to measure (e.g. weaning age) and certain taxa are overrepresented in the available data (e.g. Canidae), the following variables have been consistently measured in both captive and natural populations: gestation length, birth weight, litter size, age at weaning, age at sexual maturity (i.e. at first reproduction), age of independence (i.e. at dispersal from natal territory or establishment of foraging independence), interbirth interval, and longevity. In the following sections, we discuss the variation in these life histories in relation to size constraints, taxonomy, food habits, and ecological characteristics. [Discussions of sexual dimorphism can be found in Ralls $(245,246)$, Eisenberg (83), and Gittleman (105)].

\section{Body and Brain Size}

A close relationship between adult body or brain size and life histories is widely found in eutherian mammals $(83,210,211,319)$. All of the above life history variables correlate significantly with carnivore's adult body weight and brain weight (Table 2), and a common slope can be drawn for the whole order (see 105). Many of the slopes of life history traits are similar to those found in other mammalian groups, supporting the hypothesis that the same physiological and energetic factors produce constants in scaling throughout the Mammalia class $(51,202,319)$.

Because some error and uncertainty of dependence occurs among these variables, the slopes in Table 2 were calculated using major axis analysis, rather than standard regression techniques (126). The slope for gestation length on body weight for 93 carnivore genera is 0.10 , which is similar to Western's (319) figures for artiodactyls (0.16), primates (0.14), and carnivores (0.12), and to Kihlstrom's (148) calculations for 208 species of eutherian mammals (0.17).

Birth weight also scales similarly across diverse mammalian taxa. Using regression analysis, Leitch et al (179), Leutenegger (180), and Millar (210) independently calculated exponents between 0.63 and 0.83 for a wide array of bats and other small mammals, carnivores, and primates. The exponent for 62 genera of Carnivora, the largest representative sample thus far assembled, is 0.81 , similar to other exponential values.

Litter weight; ages at weaning, independence, and sexual maturity; and longevity also scale to both body and brain size (105). Although physical models cannot explain the precise functional causes of such 
allometric scaling $(51,203,319)$, comparative evidence on carnivore life histories warrants the inclusion of size factors in analyses of both inter- and intraspecific variation among these traits.

Table 2 Statistical relationships between 8 life history traits and adult body and brain weight across the order Carnivora (from 105)

\begin{tabular}{|c|c|c|c|c|c|c|c|}
\hline Life history trait & $\begin{array}{c}\text { Compared } \\
\text { to } \\
\text { body/brain } \\
\text { weight } \\
\end{array}$ & $\begin{array}{l}\text { No. of } \\
\text { genera }\end{array}$ & $\begin{array}{c}\text { No. of } \\
\text { families }\end{array}$ & $\begin{array}{l}\text { Correlation } \\
\text { coefficient } \\
(r)\end{array}$ & $\begin{array}{l}\text { Coefficient of } \\
\text { determination } \\
\left(r^{2}\right)\end{array}$ & $\begin{array}{c}\text { Slope of } \\
\text { major axis } \\
\text { line across } \\
\text { order }\end{array}$ & $\begin{array}{l}\text { Heterogeneity } \\
\text { across } \\
\text { families F(df) }\end{array}$ \\
\hline \multirow[t]{2}{*}{ Gestation length } & Body & 93 & 7 & 0.85 & 0.73 & 0.10 & $2.8(6,86)^{b}$ \\
\hline & Brain & 93 & 7 & 0.82 & 0.68 & 0.15 & $1.4(6,86)^{\mathrm{e}}$ \\
\hline \multirow[t]{2}{*}{ Birth weight } & Body & 62 & 6 & 0.87 & 0.75 & 0.81 & $5.7(6,54)^{d}$ \\
\hline & Brain & 62 & 6 & 0.91 & 0.83 & 1.35 & $10.45(6,54)^{d}$ \\
\hline \multirow[t]{2}{*}{ Litter weight } & Body & 59 & 6 & 0.84 & 0.71 & 0.86 & $6.1(6,52)^{d}$ \\
\hline & Brain & 59 & 6 & 0.88 & 0.78 & 1.63 & $6.3(6,52)^{d}$ \\
\hline \multirow[t]{2}{*}{ Weaning age } & Body & 62 & 6 & 0.62 & 0.38 & 0.23 & $2.5(6,55)^{a}$ \\
\hline & Brain & 62 & 6 & 0.58 & 0.34 & 0.37 & $2.4(6,55)^{a}$ \\
\hline \multirow[t]{2}{*}{ Age at independence } & Body & 26 & 4 & 0.84 & 0.71 & 0.41 & $4.6(4,23)^{\mathrm{c}}$ \\
\hline & Brain & 26 & 4 & 0.88 & 0.77 & 0.76 & $6.7(4,23)^{d}$ \\
\hline \multirow[t]{2}{*}{ Age at sexual maturity } & Body & 54 & 7 & 0.81 & 0.65 & 0.37 & $5.8(6,47)^{d}$ \\
\hline & Brain & 54 & 7 & 0.77 & 0.60 & 0.58 & $9.4(6,47)^{d}$ \\
\hline \multirow[t]{2}{*}{ Interbirth interval } & Body & 54 & 5 & 0.67 & 0.45 & 0.10 & $4.9(5,49)^{b}$ \\
\hline & Brain & 54 & 5 & 0.64 & 0.41 & 0.13 & $5.2(5,49)^{d}$ \\
\hline \multirow[t]{2}{*}{ Longevity } & Body & 48 & 7 & 0.75 & 0.57 & 0.12 & $2.4(6,41)^{a}$ \\
\hline & Brain & 48 & 7 & 0.76 & 0.58 & 0.22 & $2.2(6,41)^{\mathrm{e}}$ \\
\hline \multicolumn{8}{|l|}{${ }^{a} p<0.05$} \\
\hline \multicolumn{8}{|l|}{${ }^{\mathrm{b}} p<0.025$} \\
\hline \multicolumn{8}{|l|}{${ }^{\mathrm{c}} p<0.01$} \\
\hline \multicolumn{8}{|l|}{${ }^{\mathrm{d}} p<0.001$} \\
\hline${ }^{\mathrm{e}} p>0.05$ & & & & & & & \\
\hline
\end{tabular}

Although life history patterns across Carnivora reveal constant scaling, differences among families are evident if one compares deviations from a line of best fit for each life-history trait plotted against either body or brain weight (14 out of 16 , or $88 \%$, are statistically significant; see 105). Particularly marked familial differences are observed for relative birth weight, litter weight, age at independence and at sexual maturity, and interbirth interval (Table 2).

Thus, in comparing carnivores with other mammalian orders $(210,319)$, it is essential to recognize that variation within the order is significant among families for a number of life history traits; researchers need to account for this variation before suggesting functional explanations. Therefore, in the following discussion we focus on behavioral and ecological relationships with life histories within families.

\section{Life History Patterns and Feeding Ecology}

Carnivores are well-known for their dietetic preferences, and thus, it is not surprising that variation in carnivore life histories is associated with food habits. In the following comparisons (summarized from 105), relationships among different species have been scaled to maternal body size (indicated by our use 
of the term relatively). We divided carnivores into two groups: (a) omnivores, species in which meat constitutes less than $60 \%$ of the diet (as determined from the available literature) and (b) carnivores, species in which meat accounts for over $60 \%$ of the diet (105).

Among Canidae, omnivorous species such as black-backed jackals, fennec foxes, and crab-eating foxes have relatively heavier offspring, longer gestation periods, and lengthier periods of dependence prior to weaning, as compared to more exclusively carnivorous species such as wolves, coyotes, African wild dogs, arctic foxes, and red foxes. There is weaker evidence indicating that omnivorous canids reach sexual maturity earlier than carnivorous canids.

The differences between omnivorous and carnivorous canids may be explained in two ways. First, omnivores can choose from a wider variety of foods, and in terms of nutritional requirements, reproduction in omnivores is probably less risky. When the food supply fluctuates, a species such as the black-backed jackal, which feeds on beetles, termites, fallen fruits, berries, snakes, and various birds and mammals $(40,259,260,284)$, can maintain itself more easily than a strict carnivore. Thus, an omnivorous canid may have the energetic capacity to endure an extended period of gestation, followed by a long lactation period for relatively larger offspring.

Carnivorous species, in contrast, tend to have shorter gestation periods and give birth to lighter young, perhaps to minimize vulnerability to prey fluctuations and, consequently, to reduce maternal energetic cost of feeding offspring. Population changes seem congruent with these comparative trends. For example, during a five-year decline in coyotes' major source of prey-the snowshoe hare, Lepus americanus-in Alberta, Canada, the pregnancy rate declined over $25 \%$ and the mean litter size fell from an average of $4.9 \pm 1.1$ to $3.6 \pm 1.0(301,302)$. A similar decline in reproductive rates was observed in lynx inhabiting the same area (43).

Postweaning experiences are also markedly different in carnivores and omnivores. Carnivores progress towards the age of independence more slowly than do omnivores. Among the larger canids (wolves and coyotes) and felids (African lions, tigers, leopards, and cheetahs), which generally feed on larger-sized prey, "teaching" the young how to hunt is probably more critical in strict carnivores than in omnivores. At 12 to 15 months of age, juvenile lions, tigers, and leopards begin to make foraging excursions with their mothers, and they gradually become more successful hunters $(182,272,273)$. Mothers may also bring their young maimed prey so they can learn stalking methods and killing techniques. Lionesses may even distinguish between serious hunts, with only adults participating, and training hunts, with juveniles following and watching adults in pursuit (276).

Carnivores' relatively slow progress toward independence may therefore be related to their need for more hunting experience prior to dispersal. Except for hyenas, however, this trend only seems to apply to larger Carnivora. Smaller felids, Mustelidae, and Yiverridae--all strict carnivores that feed on small rodents-rely more on rushing and/or ambushing prey, rapidly clasping them with the forepaws, and delivering a swift killing bite $(85,182)$, rather than on the elaborate stalking procedures observed in larger species.

BODY SIZE AND DIET Haldane (117) wrote, "The most obvious differences between different animals are differences in size, but for some reason the zoologists have paid singularly little attention to them." Although this situation has improved in recent years $(51,63,237,287 a, 288,322)$, few authors of singleor cross-species studies on carnivores have analyzed behavioral and ecological differences in relation to size. Not only is size important in all species, however, but the range of body sizes found in the Carnivora is unparalleled in any other mammalian order $(105,270)$ (see Figure 1a). Such broad differences may be due to ecological effects, phylogenetic history, or both. Phylogenetic effects are frequently difficult to 
detect, and with a less than complete fossil record, they are almost impossible to explain, at least at the family level.

Available fossil specimens suggest that diet may have influenced carnivore body size (287). Fossils indicate that the first ursids, dating back to the early Miocene, were probably small forest dwellers like their miacid ancestors $(130,168)$. The Ursidae may have increased in body size as they entered more open habitats and expanded the proportion of fruits and vegetation in their diets (83).

Figure 1a Distribution of body weight (kg) across families within Carnivora (from 105). Number of species shown on ordinate. Arrow indicates median value for each family.

Figure $1 \mathrm{~b}$ Distribution of body weight $(\mathrm{kg})$ across categories of prey size (from 105). Number of species shown on ordinate. Arrow indicates median value for each prey size category.

Figure 1c Number of prey (see text for definition) plotted against body weight $(\mathrm{kg})$ for different carnivore species (105).
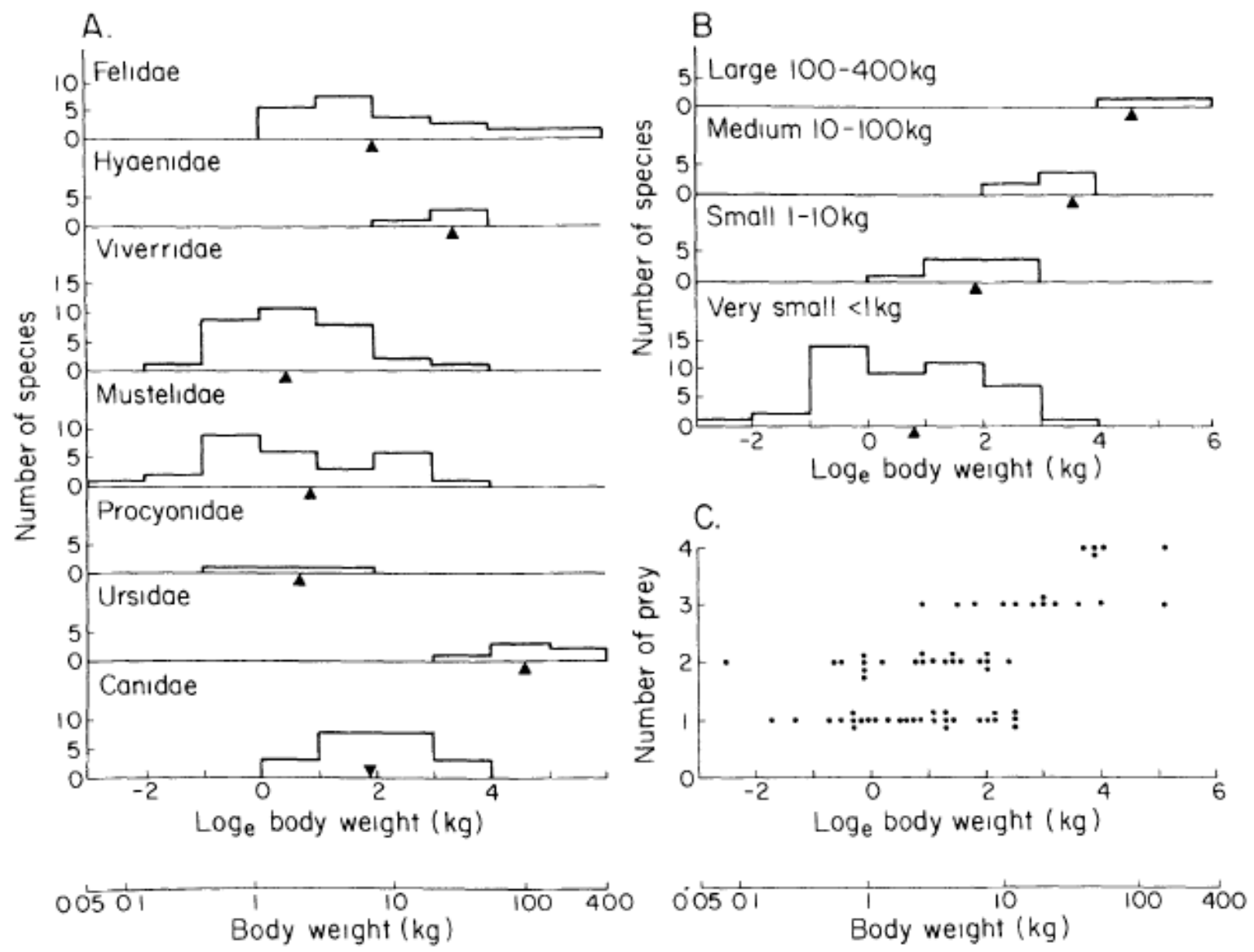

The Canidae are cursorial predators, adapted to either running down prey over considerable distances or pinning it down with large forepaws and delivering a killing bite. Selection for increased size in Canidae, as in Hyaenidae and some felids, probably occurred with the exploitation of large prey in open country habitats $(83,93,198)$. In Mustelidae and Yiverridae. smaller individuals were adapted for exploiting small 
rodent prey and invertebrates, as well as to make the predator less conspicuous in open vegetation (93). Small size in felids may also have been selected to promote arboreality (157).

Dietetic factors were probably especially important in the phylogeny of size among predatory species, where body size limits the range of available prey. Comparative data on extant species support this idea. The recent accumulation of measurements on diet and body size in carnivores permits a more comprehensive examination of this relationship (105). Prey are categorized into four size classes depending on the weight of prey that compose at least $50 \%$ of the diet: (a) very small (less than $1 \mathrm{~kg}$, e.g. the brush vole, Lagurus curtatus): (b) small (1-10 kg, e.g. the snowshoe hare, Lepus americanus); (c) medium (10--100 kg, e.g. the white-tailed deer, Odocoileus virginianus); (d) large (more than $100 \mathrm{~kg}$, e.g. the wildebeest, Connochaetes taurinus). A direct relationship between carnivore body weight and prey size is observed across 62 species (105; Figure 1b). In some respects, this trend is hardly surprising. A stoat or genet would not have the strength or energetic capacity to track, pull down, and consume a large ungulate; similarly, an African lion may not move swiftly enough to follow and pounce on a vole, nor would it be energetically efficient for it to do so habitually. Yet, small mammals may be important in the diet of large carnivores-as studies of lions living in the Kalahari suggest (M. J. Owens, personal communication).

Nevertheless, the empirical association between carnivore weight and prey weight suggests that the margin of variance in the relationship is rather slight. Aside from marked differences in prey size for extremely large or small carnivores, species such as the South American fox or bobcat are restricted, on the average, to prey of a certain size. Nonetheless, morphological characters such as long canines and claws $(93)$ and social hunting patterns $(53,228)$ may extend the limits of prey size in some cases (e.g. mountain lion, spotted hyena, wolves, African wild dog, coyotes, African lion).

Prey diversity and body size As theoretical models would lead us to expect $(278,322)$, diversity of prey may also be related to differences in body size. Prey diversity can be measured in a number of ways. In carnivores, however, detailed, species-by-species descriptions of dietary contents are only available for the well-studied canids, felids, hyaenids, and mustelids, and comparative studies are therefore restricted to a crude index of diversity based on measurement of size classes. Carnivores may be classified according to the size of both "typical" (i.e. composing at least $50 \%$ of the diet) and less common prey.

By categorizing species in this fashion (Figure 1c), we find that the number of prey size classes in the diet increases with body weight $\left(r_{69}=0.64, p<0.01\right)$. There are many possible causal factors involved. Larger carnivores tend to have greater home-range areas (107), and therefore the absolute chance of coming across a variety of preys is greater. Also, larger species probably have stronger forelimbs and wider jaws, enabling them to eat both small and large prey easily. Conversely, small species are morphologically limited to a smaller range of food and live in smaller home ranges.

The availability and abundance of prey also varies across different size classes. Smaller carnivores (e.g. gray fox, stoat, European wild cat) can specialize on small rodents such as Peromyscus or Microtus that reach high population densities and remain fairly common. In contrast, it would be difficult, if not impossible, for species like the African lion, mountain lion, or spotted hyena to specialize on large ungulates the size of water buffalo (Syncerrus caffer) or elk (Cervus canadensis), which have lower population densities and turnover rates. Larger carnivores must maintain t1exible dietetic preferences in order to increase the absolute number of potential foods.

The advantages of increased prey diversity for large carnivores have been poorly studied. At southern latitudes in mainland Chile where the South American fox and the Chico gray fox are sympatric and differ in size, the former is larger and feeds on a greater variety of rodent species than the latter, independent of prey distribution (103). Thus, in some instances, diversity may be just as salient a factor as prey size in 
the selection of carnivore body size. A causal relationship has not been established, however, and diversity may be the result of increased body size, not the factor selecting for it.

\section{Life History Patterns and Habitat}

Interspecific differences in carnivore life histories are also associated with vegetation or habitat types. In Canidae, open grassland species (African wild dogs, arctic foxes) have relatively lighter birth weights than open grassland or woodland species (South American foxes, crab-eating foxes) or forest dwellers (dholes, red foxes). In Felidae, species living in sparse woodlands (mountain lions, Geoffrey's cats, leopards) have lighter total litter weights (litter size times birth weight) than do forest-living species (bengal cats, ocelots, lynx, tigers, jaguars). In explaining absolute differences in litter size between Canidae and Felidae, Kleiman \& Eisenberg (157) argued that carnivores living in more forested habitats have a diversified food base, including both arboreal and terrestrial prey, that is not available in open grassland or sparse woodland terrain.

Spatial heterogeneity is also reflected in contrasting environments: Forest habitats may present more perceptual and ranging complexity than open grassland or savannah areas (83). In a study of a relatively small sample of Mustelidae, Gittleman (105) found that females of forest-living species (stoats, American minks, American martens, fishers) and aquatic forms (European otters, sea otters) reach sexual maturity later than open grassland/woodland species (long-tailed weasels, European badgers) and open grassland/forest species (wolverines, striped skunks).

Few detailed data are available on postnatal development, maternal care, natal dispersal, or establishment of territory in species of Mustela or Martes $(291,292,296)$ because of their solitary existence. Behavioral observations on the aquatic European otters and sea otters, however, indicate that in addition to maternal care, both species have unusually long and attentive periods of adult care (269). Sea otter pups are usually born in the water and are supported on the mother's chest as she swims on her back $(146,147)$. The demands of foraging for scarce foods in oceanic waters and of locating areas protected from heavy seas may select for delayed sexual maturity to ensure familiarity and effective utilization of the environment so that young may be reared successfully $(146,277)$.

\section{Life History Patterns and Social Organization}

As important as ecological effects on life history patterns is the social environment in which life histories evolve $(19,20,24,106,193)$. In many carnivores (wolves, coyotes, dwarf mongoose, lion), subadults and adults assist in provisioning, guarding, and socializing young born into the social group. Helping (alloparental) behavior or communal rearing may select for life history patterns that diverge from the traits found in species in which maternal or even biparental care is prevalent. Across Canidae--after controlling for size-birth weight, litter weight, age at which females first breed, and age at independence all increase with the degree of sociality, which is defined as the average number of individuals associating during the rearing of young (24). Moreover, across all Carnivora, species in which communal rearing is common reach sexual maturity later and have heavier litters than species in which maternal or biparental care is the modal pattern (106).

The causal mechanisms underlying these comparative trends are difficult to pinpoint. However, recent detailed field studies on the effects of helping (see below) may further our understanding of the relationship between intra- and interspecific variation in the association between life history traits and patterns of care-giving. In various canids, for example, individuals other than parents sometimes contribute directly to feeding young or parents and to guarding the den site. In black-backed and golden jackals, helpers-usually nonbreeding adults $11-20$ months old-spend about $55 \%$ of their time at dens 
protecting pups, regularly contribute food to the young and to the lactating mother by regurgitation, and defend carcasses for utilization by the entire pack (222; for comparative data see $27,29,123,195,214$, $217,229,231)$.

In some species, food provisioning does not appear to be a major part of helping $(29,171,254--257)$, which primarily involves den sitting. Either food provisioning or den sitting may provide the necessary energetic requirements to select for differences in birth weight, litter size, or natal dispersal $(29,106)$. How helping actually affects life history patterns is unknown, however, and deserves careful attention in future research programs.

\section{SOCIAL ECOLOGY AND SOCIAL ORGANIZATION}

\section{Methods of Study and Data Analysis: Observation and Radio-Tracking}

The first step in obtaining detailed information about patterns of social organization is the compilation of ethograms, or behavioral repertoires, based on direct observation. This process involves describing basic motor patterns unambiguously, so that observers can reliably record the repeated occurrence of a particular behavior and other people can know exactly what was observed. Comparative analyses of social interaction patterns and the behavior involved rely on these basic descriptive data, especially when frequencies or rates of occurrence are used to differentiate closely related species (for data on carnivores, see $13,15,17,25,38,156,157)$.

Although many carnivores are difficult to study under field conditions, social interaction patterns and spatial relationships among individuals must be rigorously analyzed and quantitatively assessed $(65,115$, $127,178,188,201,236,304)$. For example, quantitative measures of association patterns $(178,188$, 236), dominance relationships $(14,57)$, and territorial behavior (on the defense function, see 208; on the index of defendability, see 219; see also 145) have been used successfully for other animals, but they are just as applicable to analyses of carnivore social patterns.

Multivariate statistical procedures can also provide detailed information about social organization and basic behavioral patterns $(14,17,18,29,65,127,136,314,315)$. As Hilborn \& Stearns (132) pointed out, evolutionary biologists must look for multiple causes; single factor studies may delay progress when multicausal factors are actually operating-as they usually are (see 83). Statistical analyses at any level, however, cannot substitute for inadequate investigation and description of the "deep structure" of the problem at hand (109).

It is clearly important to gather observational data in any study of social organization. Most carnivores are difficult to observe or even to locate on command, however; many species are nocturnal and/or very secretive, and they move about rapidly. In these cases, observation must be supplemented by radiotracking (for reviews of this technique, see $7,59,207$ ). Radiotelemetry allows us to track individual animals over long distances and often for long periods of time. Biological attraction points (74) that influence movement patterns can also be detected. In addition, radio-tracking permits researchers to locate animals that cannot be seen and to assess spatial relationships among individuals with some degree of accuracy. As Macdonald (191) stressed, though, accurately and reliably interpreting the social significance of movements of radio-tagged animals (in his case, red foxes) poses many problems. In addition to not knowing what the interacting animals are doing to one another, it is difficult to assess whether their movements are independent or correlated (76).

One important methodological problem with radio-tracking free-ranging animals is that for many species, home range (territory) estimates are positively correlated with the number of radio locations gathered (for a review, see 26). Simulations relating area estimates to sample size (Figure 2) and analyses of the 
available literature (175) indicate that in many instances, the samples used to estimate space use have been too small. The number of locations that constitute an adequate sample may vary with a species' size, the season (e.g. presence of snow), habitat, sex, age, social status (resident, transient, or group member), reproductive condition, food resources, and the presence or absence of conspecifics or other species; what is sufficient for one individual may be inadequate for another. Field workers relying heavily on telemetry need to show that sample size is not a confounding variable. Radio-tracking can be a valuable tool in the study of social ecology and social organization when the effects of sample size and the accuracy with which signals can be located are taken into account.

Figure 2 The relationship between estimated mean home range size (indicated by solid line) and variability (indicated by slashed line) (coefficient of variation) and number of locations. "0.50N polygon" and "0.95N polygon" refer to the convex polygons that encompass $50 \mathrm{o} / \mathrm{c}$ and $95 \%$ of the total number of locations $(\mathrm{N})$. The results of the present simulation indicate that, on average, field workers should obtain between 100 and 200 locations in order to estimate the home range area ( $N$ within which mean area and variability level off) reliably. Sampling differences for small species occupying relatively small home ranges indicate that fewer locations may be sufficient, and variability in social status, age, sex, and reproductive condition also have to be considered, as do food resources, habitat (terrain, plains, forests) and differences in sampling and analytical methods (see 26 and 30).

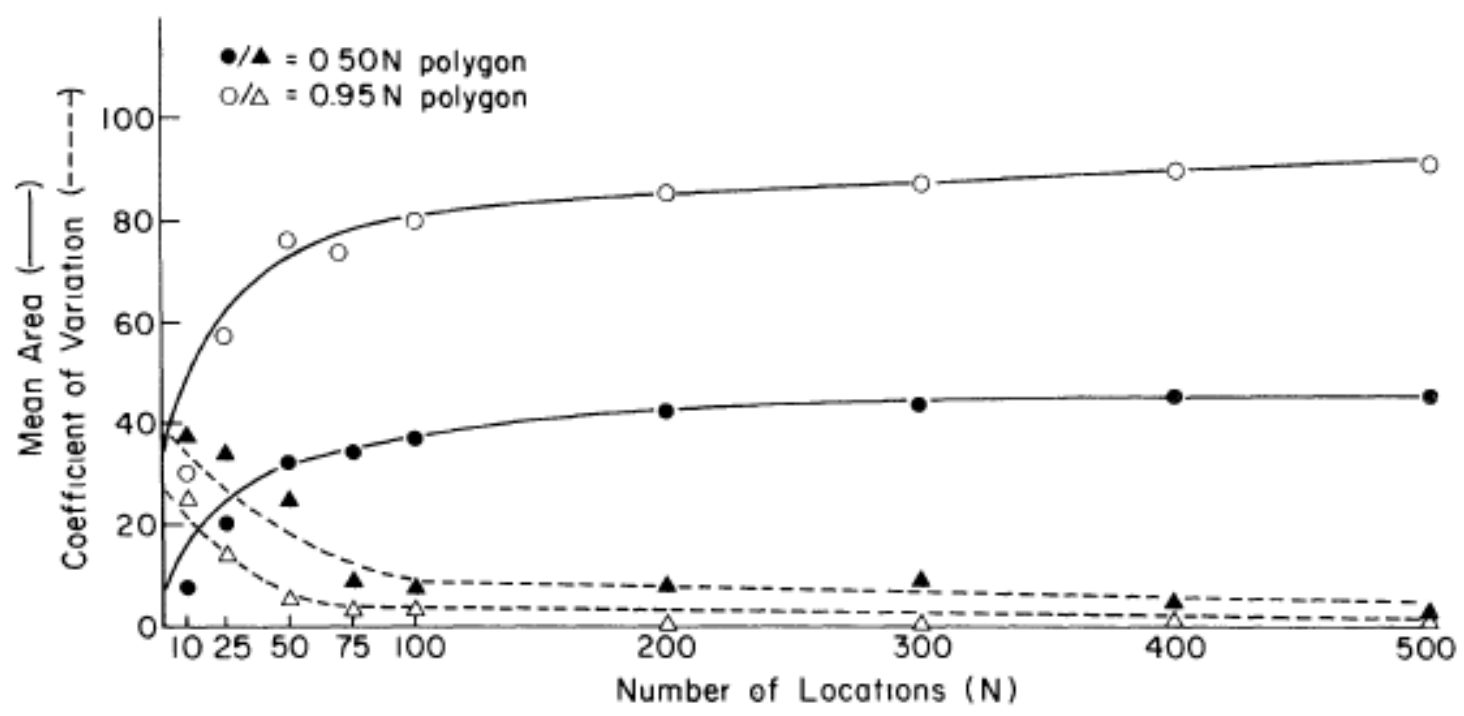

Assessing Kin Relationships

In order to conduct detailed analyses of carnivore social organization genetic (kin) relationships (Figure 3) must also be determined whenever possible in order to assess the relative roles of kin selection (39, 118, $119,321,324)$ and other possible pathways--e.g. reciprocity, mutualism, and indirect effects (323)--in the evolution of different forms of social behavior $(9,19,20,29,39,45,46,49,58,83,96,194,234,248$, $257,279,306)$. For some carnivores exhibiting complex patterns of social organization, kin selection alone may be inadequate to account for observed behavioral interactions [e.g. dwarf mongooses (257), African wild dogs (248), coyotes (29), lions (234), and brown hyenas (231)]. The relative importance of different mechanisms may vary among individuals as well.

Kin relationships within social groups-as measured by the coefficient of genetic relationship, $r$-vary among species of social carnivores ( $r$ equals $0.125-0.5$ in African wild dogs, 0.38 in red foxes, 0.5 in Arctic foxes and in jackals, $0.15-0.22$ in lions, and 0.03 in spotted hyenas; data from 194). These coefficients may 
differ with age and sex $(34,37)$ as well, as a result of differences in patterns of dispersal and philopatry. In many instances, the kin relationships are not actually known, and they are inferred from social interaction patterns with varying degrees of accuracy. The importance of determining kin relationships is demonstrated by an often cited example of kin selection from an excellent field study of wild turkeys (Meleagris gallapavo; 312) that may be flawed because relationships among the birds were not known (11).

Figure 3 Social groups of carnivores often are comprised mostly of genetically related individuals (extended families). This figure presents a pedigree for a pack of coyotes observed in the Grand Teton National Park, outside of Jackson, Wyoming, from 1977 to 1983 (28, 29, 314, 315). Young of each year that are accounted for either dispersed or died before they were about 9 months of age. After the original pack mother (Mother 1) left the group in late 1980, a new and unrelated female (Mother 2) joined the pack and mated with the original pack father (Father 1) in 1981. Then, after he left the pack in spring 1981, his son, male helper B21, mated with the new female in 1982 and 1983. In 1982, the help that B21 provided to male '81 and female B36 was reciprocated when B21 and the new female's pups were born. The new pack mother was the only unrelated coyote to join the pack in 6 years (see 29 for details).

Figure 3 Social groups of carnivores often are comprised mostly of genetically related individuals (extended families). This figure presents a pedigree for a pack of coyotes observed in the Grand Teton National Park, outside of Jackson, Wyoming, from 1977 to $1983(28,29,314,315)$. Young of each year that are accounted for either dispersed or died before they were about 9 months of age. After the original pack mother (Mother 1) left the group in late 1980, a new and unrelated female (Mother 2) joined the pack and mated with the original pack father (Father 1) in 1981. Then, after he left the pack in spring 1981, his son, male helper B21, mated with the new female in 1982 and 1983. In 1982, the help that B21 provided to male' 81 and female B36 was reciprocated when B21 and the new female's pups were born. The new pack mother was the only unrelated coyote to join the pack in 6 years (see 29 for details).

PACK PEDIGREE: $1977-1983$

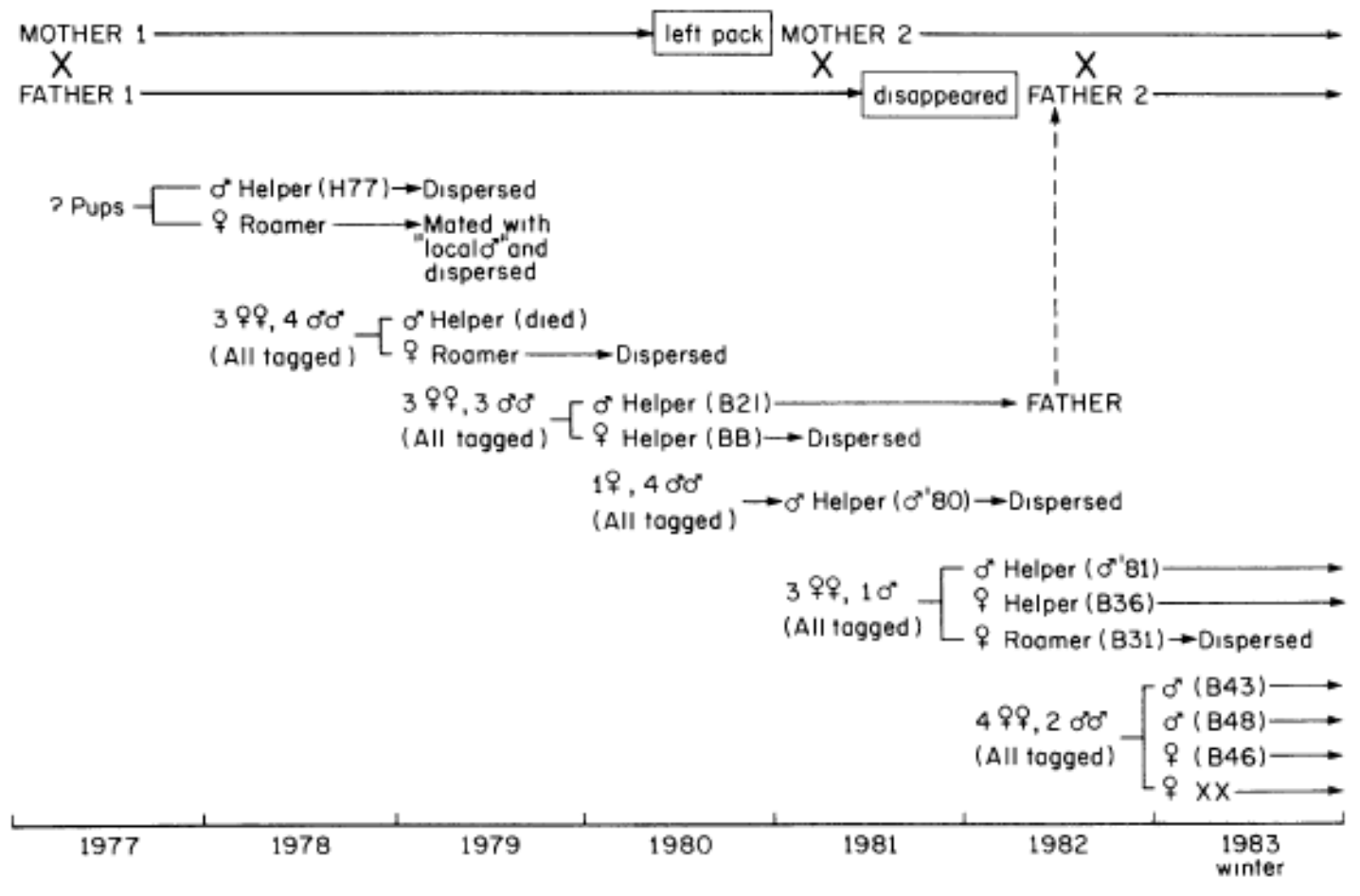




\section{CARNIVORE SOCIAL GROUPS}

In addition to the widespread but predictable differences in relative life history patterns among carnivores, there is considerable variation in social organization. Groups vary in size from lone individuals to packs of over 10 animals, age and sex ratios differ greatly, and group members may or may not be closely related. Although some species are typically considered to be "solitary" outside of the breeding season and caregiving period (e.g. felids other than lions and most mustelids and viverrids), Leyhausen (182, p. 257) has correctly stated that "the only mammal one could conceivably speak of as being socially indifferent is a dead one." Field data clearly show that members of solitary species communicate with one another using olfactory, auditory, and even visual signals, and through this exchange of information, they are able to avoid contact and maintain nonoverlapping home ranges or territories (whose boundaries are actively defended).

In some cases, intraspecific variation in social organization, due primarily to differences in food resources and habitat, is at least as pronounced as interspecific differences [coyotes (29), wolves (124), Kalahari lions (M. J. Owens, personal communication), brown hyenas (232), golden jackals (190), striped hyenas $(163,189)$, red foxes $(186,187,191,192,331)$, raccoons (102), spotted hyenas (161), and African wild dogs $(100,248)]$. Although extreme intraspecific variation appears to be rare among carnivores in general, it may be misleading to characterize some species' social organization as having a modal group size (solitary or social), a typical group composition, or active defense of territorial boundaries.

Nonetheless, Altmann \& Altmann (6) pointed out that animals' behavior and social organization often exhibit a range of species-specific stereotypy that is much narrower than one would expect based on experimentally demonstrated capacities for plasticity. Stressing that behavior is an important aspect of the environment, they argue that consistency in social interaction patterns among group members is made possible by the heritable component in some life history patterns. Although there is intraspecific variation in social organization among conspecifics living in different areas within a given habitat, where food resources do not drastically change, successive generations do adopt similar social organizations [coyotes $(27,29)$, African wild dog (100), and lion (32, 34-36, 120, 273)] with respect to most or all of the following variables: group size, group composition, patterns of emigration and space use, and mating and care-giving habits.

\section{How Social Groups are Formed and Maintained}

Understanding the many interrelated behavioral processes involved in social group formation and maintenance requires at least: (a) analyzing the development and maintenance of social bonds and relationships among offspring and between younger and older individuals (15, 20, 23, 134); (b) studying social interaction patterns between older group members and "outsiders"; (c) determining movement patterns for individuals identified by sex and age; and, in the best of all possible worlds, (d) learning enough about the behavioral patterns of dispersers and nondispersers to make educated guesses about how individual movement patterns influence reproductive fitness--e.g. Do resident animals help rear offspring born into the group? Do nondispersing individuals eventually inherit a portion of their natal area? Do dispersers breed at an earlier age than individuals remaining in their natal territory? Do dispersers suffer higher mortality rates than nondispersers? (see 20, 100, 120, 194, 311 for detailed discussions).

DEVELOPMENTAL ANALYSES OF SOCIAL BEHAVIOR Comprehensive studies of behavior must consider at least four major topics: evolution, adaptation, causation, and development $(299,300)$. While it may be beyond the ability of any one researcher to provide substantive answers to questions in all four areas, a complete analysis ultimately rests on the generation of data in all of them. Because every 
population is age structured (56), developmental questions are important to consider in evolutionary and ecological research in social biology (23).

Ontogenetic trajectories A general concept applicable to both carnivores and other taxa is Wiley's (320) model of ontogenetic trajectories, in which movements of individuals through different social positions are described. This analysis can be used to trace longitudinally how individuals become incorporated into social groups (Figure 3) and to determine if variations in the natal environment affect development and later behavior (122). Wiley (320) related the evolution of different mating and social systems to ontogenetic profiles that differed in the age at sexual maturity, and he stressed that delayed reproduction is not a secondary consequence of social organization.

Wiley also pointed out that the evolution of complex social organizations is inextricably linked to the evolution of an optimal allocation of effort among reproduction, growth, and maintenance throughout an individual's lifetime. His model of ontogenetic trajectories highlights the complex trade-offs among demographic variables such as age at sexual maturity, fecundity, mortality, and developmental pathways (see also 56, 298). Clearly, life history and demographic analyses are important in studying the relationship between behavioral development and the evolution of sociality $(8,24,94)$.

Development and social organization A major difficulty in relating patterns of behavioral development to social organization is that developmental data are extremely difficult to gather under field conditions. Nonetheless, limited field data and information from captive animals concerning the ontogeny of social relationships indicate that even among closely related species $(15,17,20,38)$, interspecific differences in social organization may be associated with variations in behavioral development. Similar results have been reported for rodents $(121,325)$ and Bighorn sheep [Ovis canadensis (31)].

Apart from the problems of gathering developmental field data, intraspecific variability in social organization is highly pronounced in some taxa, making interspecific comparisons difficult. It is not known whether these intraspecific differences are reflected in variations in early social development in carnivores, as they are in Bighorn sheep (31) and lemurs [Lemur spp. (295)]. Field observations of coyote pups born in different habitats and into different types of social groups do not reveal any major variations in development during early life (M. Bekoff, unpublished data). But it is entirely possible that observed differences in social interaction patterns and spatial relationships among older siblings and between parents and offspring in coyote populations displaying different organizational patterns (solitary individuals, mated pairs, packs) are associated with varying developmental profiles, as perhaps are interspecific differences in social organization among some canids $(20,38)$. In polar bears, for example, population density influences association patterns among age and sex classes, and as a result, social organization varies (173).

To the best of our knowledge, there are no longitudinal field data for carnivores that can be used to support or refute with any degree of certainty hypotheses about the relationship between development and intraspecific variations in social organization. While there may be differences in a single species' behavioral repertoire that are dependent on habitat and parallel observed interspecific variations, this pattern apparently is not found in canids, at least. A fruitful area for further comparative study would be the analysis of differences in the frequency (or rate) of occurrence of shared behavioral patterns among carnivores $(156,157)$, similar to the studies done among different species of can ids (see 15, 17, 25 and references therein).

Social play behavior Variations in early social play experience may influence the development and maintenance of social bonds within a group of animals and consequently affect social interaction patterns among all group members, individual movement patterns, and the social organization in general $(15,21$, 
$22,88,94,174,332)$. Detailed field data relating individual patterns of social play to later behavior are lacking and are needed to verify what appear to be robust findings based on captive animals. Information also needs to be collected on age and sex differences, variations related to social rank $(15,21,192)$, and the distribution of different types of social play according to the sex, age, rank, and genetic relatedness of the participants.

SOCIAL INTERACTION PATTERNS BETWEEN OLDER GROUP MEMBERS AND OUTSIDERS Another perspective on group formation and maintenance can be gained by studying how resident group members interact with outsiders that may be incorporated into the group. Limited comparative data indicate that some organized carnivore groups (i.e. not temporary aggregations) are relatively closed to outsiders (e.g. coyotes, jackals, and wolves); new members are rarely accepted into what are essentially extended family groups (29, 204; see also 303). In a six-year study of coyotes (29), a strange adult female was the only individual incorporated into a stable coyote pack. She was accepted after the breeding female left the group and subsequently mated with the only breeding male in the group. After he departed, she successfully bred two times with his son, who had previously been a helper (male B-21 in 29; see Figure 3). In dwarf mongooses (257) and Kalahari lions (M. J. Owens \& D. D. Owens, personal communication), however, males and females commonly transfer between groups.

The permeability of relatively closed societies, as well as the openness of other types of social groups, may be influenced by age and sex differences in the degree of aggression toward outsiders or by the loss of social cohesion due to environmental stresses (M. J. Owens \& D. D. Owens, personal communication). Individuals of different social rank may also vary in their attitude toward admitting new group members $(48,98)$. Young animals are usually more accepting of new group members than older, high-ranking individuals. The heightened level of aggression among members of the same sex also appears to influence group composition in diverse carnivores $(32,87,100,218,222,230,240,248,294,328)$.

SOCIAL ECOLOGY, DISPERSAL, AND PHILOPATRY Dispersal (i.e. the movement of individuals away from their place of birth) and natal philopatry (i.e. the continued residence of animals at their birthplace. past the age of independence; see 311 ) directly influence social organization and breeding patterns ( 6 , $15,20,27,29,100,104,114,120,194,222,223 a, 311)$. The dispersal patterns of both young and older individuals--primary and secondary emigration, respectively (100)--need to be studied further; they may vary with age, sex, and social rank. The benefits and risks associated with remaining in the natal area (possibly inheriting part or all of the natal home range or territory, providing help in rearing individuals born into the group, delaying breeding in groups where only one male and female typically breed) and dispersing (leaving a group in which breeding is unlikely or in which an individual is socially incompatible with other group members, the possibility of pairing and breeding, the possibility of increased mortality) must be considered in each specific instance.

Among wide-ranging carnivores, the difficulty of analyzing movement patterns is obvious. Radio-tracking combined with direct observation is essential, and individuals must be marked as early in life as possible. In many instances, young animals leave their natal groups and change morphologically (size, coat characteristics) between sightings. Individuals may also leave their natal area and return at a later date $(29,194)$, or they may leave alone and then be seen with other animals with which they may not have been previously associated. The fates of littermates that disperse together and of different-aged siblings that depart at different times also needs to be documented (100).

Many interrelated factors such as population density, food resources, and the cumulative effects of social interactions undoubtedly influence an individual's own "decisions" about whether or not to leave its natal area. These same factors probably result in involuntary dispersal by some individuals that might otherwise have remained; departure can be caused by aggression between littermates, siblings, older 
group members, parents and offspring, and/or adults and unrelated younger animals $(15,32,142,151$, 154, 204, 330).

In lions, Elliott \& McTaggart Cowan (87) reported a positive relationship between population density and the age at which subadults are expelled from the pride $(265,273)$. Bertram $(32)$ concluded that pride size in lions is regulated by density-dependent recruitment or expulsion of subadult females. Although lion population density is influenced by food availability and social behavior, expulsion of females often occurred when food did not appear to be in short supply. He stressed the behavioral regulation of lion pride size (which may also apply to wolves), suggesting that this type of regulatory mechanism may be influenced by a pride's experience of past food shortages or its assessment of probable future shortages (see 286 for a discussion of prospective assessments of food resources). Pride size did not change in response to short-term changes in food availability. Kalahari lion pride members, however, do disband and disperse during periodic, severe droughts when large antelope prey become scarce (M. J. Owens \& D. D. Owens, personal communication).

Food resources seem to have a major influence on dispersal in other carnivores $(29,88,102,123,153$, $185,191,192,225,232,309,311,330$ ), and differences in food availability-in quality, quantity, and distribution-are primarily responsible for intraspecific variation in social organization. When food is in short supply, dispersal is usually more pronounced. Animals may leave because they are hungry (309), or they may be driven out by more dominant individuals.

Age, social rank, and differential dispersal Age and social rank are positively related in many carnivores. Consequently, youngsters may be unable to compete for necessary resources, including mates, and may be more disposed than older animals to leave their natal group (32, 87, 101, 185, 192, 309).

In African wild dogs living on the Serengeti Plains in northern Tanzania, individuals (usually females) commonly leave their natal pack when there is a dominant breeder of the same sex (usually a parent) present $(100)$. Reich $(247,248)$ described a unique situation in which a female wild dog supplanted her mother and then mated with her father and older brother in two successive years.

In wolves, young socially subordinate individuals may get smaller rations from each kill (also observed in lions; 32), and hunger may increase subordinates' tendency to split off from their natal pack and form small hunting groups (309 and references therein). Wolves may also leave large packs, however, when there is no indication that food is in short supply. Therefore, as in lions, leopards (294), and probably most other carnivores, social and ecological factors need to be considered together $(204-206,233,309,330)$. Fritts \& Mech (101) also noted that subordinate wolves tend to occupy the edge of their pack's territory or travel outside the territorial boundaries, perhaps obtaining information on the potential for colonization outside or at the edge of their natal pack's territory. Furthermore, wolves approaching breeding age often disperse early and attempt to form new social units, rather than trying to breed within their natal packs.

In addition to studying the association between social rank and age, the development of dominance relationships among littermates must be considered in a discussion of dispersal and philopatry (15, 20, 222,330 ). Differential dispersal among littermates is common and may be related to relative dominance status. Because dispersal is risky $(29,32,87,120,185,192,222,289,330)$, dominant individuals should be likely to exercise their prerogative and drive out subordinate littermates. Aggression between siblings of the same sex may be heightened further (222).

Both dominant and subordinate individuals may be predisposed to leave their natal groups because of an inability to develop strong social bonds, though for different reasons $(15,20)$. Based on data on captive coyotes, it has been postulated that dominant animals may disperse because other littermates avoid or 
constantly challenge them, whereas subordinate animals may disperse because they are scapegoats and actively avoid their siblings (15).

Golightly's (108) data on the relationship between social rank and energetics in juvenile coyotes indicate that high- and low-ranking coyotes have substantially higher daily metabolic rates than middle-ranking individuals, probably due to the regular challenges to which dominant individuals are subjected and to continued harassment of the subordinate coyote by other group members; the subordinate individual spends considerable effort avoiding interactions. Unfortunately, there are no field data on the comparative dispersal patterns of individuals with different social ranks or on rank-related energetics. But, as Golightly pointed out, the possible energetic advantages to dispersing must be considered along with other potential benefits (also see 48).

Sex differences in dispersal Some researchers argue that among mammals, males tend to disperse more and further than females do (114), which appears to be related to a polygamous mating system (the predominant mammalian pattern). While this sex bias may hold true for some carnivores and other mammals, there are notable exceptions in at least mountain lions (280), brown hyenas (214), dwarf mongooses (257), and African wild dogs (99, 100; but see 248). In brown hyenas, both males and females disperse, apparently in order to increase their chances of breeding. Males leave their natal group and become nomadic (males living in groups were not observed to mate), while females disperse to seek a vacated territory [see Mills (214); his data were collected in the southern Kalahari]. In the central Kalahari, dispersal by female brown hyenas is less common than male emigration (231). In dwarf mongooses, males and females commonly transfer between groups (257). Female dispersal appears to predominate in African wild dogs $(99,100)$, but the pattern may vary from one habitat to another $(248)$. In lions, new prides may be formed when subadult females leave their parent pride and settle in an adjacent area (120; M. J. Owens \& D. D. Owens, personal communication). For most other carnivores, sufficient data are not available for any categorical generalizations to be made.

The complex relationships among behavioral, ecological, genetic, and possibly energetic factors are extremely difficult to tease apart under field conditions, and intraspecific and interspecific differences should be anticipated. Whether or not specific dispersal patterns have evolved because they favor outbreeding (i.e. reduce potential inbreeding depression) $(100,223 a, 280)$ is not clear, because data for inbreeding depression in wild populations of carnivores are, at best, scanty and inconclusive $(248,281$, $282,329)$. Wolves, for example, may be highly inbred $(204,238,329)$ and still not suffer from inbreeding depression. Eisenberg (82) noted that the structure of many natural populations may be a mosaic of highly inbred subpopulations.

\section{WHY DO SOME CARNIVORES LIVE IN GROUPS?}

Although animals that live in groups have attracted a disproportionate amount of attention, group living has evolved in only $10 \%$ to $15 \%$ of carnivore species (105). Comparative information on typically solitary species such as felids $(37,182,274,280,293,294)$ and a canid [the maned wolf $(73)$ ] has also increased our understanding of the evolution of social groups in other taxa, and it has become clear that solitary does not mean asocial (181).

Our discussion will concentrate on the possible benefits of grouping, but there may also be costs associated with living in a group. These costs include an increased probability of detection by potential competitors and predators, decreased food availability per individual, increased transmission of ectoparasites and diseases $(55,191)$, and increased probability of aggression (and injury) among group members. The costs and benefits of group living are not necessarily additive (200) and may differ for 
each individual. (General comparative reviews of the evolution of sociality and group living can be found in the following references: $3,36,37,42,48,69,70,81,83,105,157,209,264,317,318,322,326$.

\section{A Classification of Carnivore Groups}

Gittleman (105) has classified carnivore groups into four major types: (a) population groups-individuals sharing a common home range; (b) feeding groups-individuals utilizing the same food resources at a given time; (c) foraging groups-individuals banding together while searching for food or hunting; and (d) breeding groups-individuals forming a reproductive unit. Population, feeding, and foraging groups are identical for most carnivores that have been studied. In some species, population group size is related to feeding group size but not to foraging group size (wolves, spotted hyenas, brown hyenas, lions, coyotes); populations may break up into smaller hunting groups and then regroup when feeding.

OPTIMAL GROUP SIZE Group size varies both inter- and intraspecifically, but there appears to be an optimal range within which individual group members benefit the most $(37,48,53,70,91,111,157,161$, $169,170,172,228,252,273$ ), especially with respect to the exploitation of food resources and individual energy budgets. Caraco \& Wolf (53) determined that lions achieve highest individual efficiency (capture success, food availability/lion, food intake/lion) in groups of two, regardless of prey size, whereas Nudds's (228) analysis showed that optimal pack size for wolves is a function of prey size.

For both lions and wolves, groups often exceed the size calculated as optimal for hunting efficiency. For wolves at least, the addition of individuals to an optimally sized pack appears to be less costly in terms of individuals' energy returns than a reduction below the optimum (228). Rodman (252) pointed out that the genetic gain through relatedness (i.e. increases in inclusive fitness) may offset the disadvantage to individual group members when surplus members are kin. Thus, despite possible costs to individual fitness, groups may evolve because of the increase in total relatedness. Competition may also promote large groups among predators that defend their kills against scavengers $(37,91,169)$.

Despite possible genetic gains and the increased ability to catch prey and defend kills in larger than optimally sized groups, an upper limit on group size is imposed by: (a) decreased hunting success (70, 273), (b) reduced food intake per individual because of increased within-group competition, and (c) the need for small- to medium-sized predators to reduce competitive pressure by hunting and feeding inconspicuously (169), among other factors. Foraging groups that are smaller or larger than expected may form, however, when prey loss needs to be minimized (169).

Group size may also be limited by small carnivores' need to decrease the likelihood of detection by potential predators $(110,256,257)$. Suffice it to say, what is optimal in one setting may not be in another, even for conspecifics. Furthermore, in determining the optimal group size for a given species, researchers must take into account all possible variables, not just food exploitation $(169,252)$.

INFLUENCE OF HABITAT ON CARNIVORE SOCIAL GROUPS Comparisons of closely related species living in similar and different habitats provide additional information on the evolution of carnivore social groups $(105,110,157,228,248,256,272-274,280,293)$. In general, species living in open grassland or in both open grassland and woodland habitats have larger population groups than forest dwellers (105), but the nature of food resources $(73,141,204)$ and competition can alter group sizes on the local level.

For predators, an open environment usually increases the chance of being detected by prey, and some form of group hunting is required for successful predation, especially on prey larger than the individual hunters. For smaller carnivores, such as mongooses, the risk of predation is greater in open habitats, and larger groups afford more protection and increased vigilance $(79,256)$; increased detection by predators could impose an upper limit on group size in the absence of behavioral regulation. Food resources are 
usually readily available to the many small carnivores for which anti predatory defense is the major force behind sociality $(105,310)$. Most smaller carnivores displaying group defense are insectivores, and Waser's (310) model indicated that a mongoose excluding a single competitor from its foraging range would only gain about $1 \%$ in prey density. Thus, prey distribution and abundance may be a precondition for the evolution of grouping in response to the need for group vigilance (105).

A comparison of lions-the only highly social felid-with a closely related, morphologically similar solitary species such as the tiger illustrates nicely the role of habitat in the evolution of felid sociality (293). In Nepal, tigers live in dense, broken terrain, where small-sized prey are scattered and difficult to locate. Successful predation requires stalking and ambushing techniques. The necessity for crypticity along with the maintenance of an almost exclusively meat diet appears to have favored a solitary existence among tigers and other felids occupying similar habitats, such as mountain lions (280), jaguars, and leopards (274). Sociality in lions, on the other hand, seems related to increased hunting and feeding efficiency and the necessity of defending large kills in open savannah habitats $(36,53,273)$. Similar selective pressures (open habitat and ungulates that were rapidly evolving into large-bodied, long-legged, fast-moving prey) also appear to have favored the evolution of sociality in wolves $(157,228)$.

\section{COMPARATIVE SOCIAL ECOLOGY: THE PERVASIVE INFLUENCE OF FOOD}

As we have repeatedly stressed above, the way in which food resources are exploited (located, hunted, scavenged, defended) and the nature of the available food (quality, quantity, spatial distribution) strongly influence interspecific relationships and result in marked intraspecific variations in social organization.

\section{Interspecific Relationships}

Radinsky's (242-244) studies of the evolution of skull shape in carnivores provide a paleoethological perspective on interspecific competition suggesting that the partitioning of prey resources by size--due to anatomical differences may have been a factor in the initial radiation of carnivores. This finding is consistent with Rosenzweig's (258) suggestion that sympatric carnivores can coexist in "hunting sets" because they specialize on prey of different sizes. There are comparative data on differential prey size selection by sympatric carnivores for viverrids [white-tailed mongooses, large spotted genets, and African civets (137)], hyaenids (12), and canids and felids (37, 167, 172, 239).

Even if different species share the same prey, variations in hunting methods, prey selection, activity patterns (time-sharing), and mutual avoidance can foster coexistence (12, 37, 137, 139, 172, 224, 297). Bertram (37) has reviewed patterns of coexistence among five carnivores that inhabit the Serengeti Plains (cheetah, leopard, lion, spotted hyena, and wild dog), all of which feed on ungulates. Differences in hunting methods (stalking or pursuing), preferred prey, activity patterns, and prey selection (in terms of age/sex and health) all interact to reduce competition and promote coexistence. Social hunters (lions, wild dogs, spotted hyenas), which use various methods to pursue prey, tend to live in long-lasting social groups, whereas cheetahs and leopards, which predominantly hunt alone, live in groups containing only one adult. Cheetahs, which suffer extreme competition from spotted hyenas (224) and lions (172), actively avoid these and other competitors and eat fast at kills. They are too light and fragile to defend kills successfully, and they can be displaced from food by any animal larger than a jackal (172).

\section{Intraspecific Variation in Social Organization}

With few exceptions, intraspecific variation in carnivore social organization as a response to local food resources is the rule among species in which group living is associated with the exploitation of food resources by group members (canids: $28,29,41,72,88,95,100,101,123,131,160,190,192,193$, 204-206, 222, 248, 261, 262, 309, 330, 332; felids: 32, 35, 36, 120, 138, 183, 235, 273; brown hyenas: 
$215,230,232$; striped hyenas: 163,189 ; spotted hyenas: $161,162,184)$. It is also prevalent in species in which the availability of ample food permits aggregations to form, but in which exploitation of food is not typically a group affair (mustclids: 149, 164, 165; procyonids: 102; ursids: 10, 66, 67, 177, 225; brown and striped hyenas may also fit into this category, see 163, 214, 232). For example, when abundant food is clumped and economically defendable (44, 111), coyotes $(29,41,52$, and Figures 3 \& 4), golden jackals (190), Kalahari desert lions (M. J. Owens \& D. D. Owens, personal communication), domestic cats (138), and striped hyenas (189) show increases in population and feeding group size and decreases in territorial area. They may also defend food resources and territorial boundaries if intruder pressure increases.

Figure 4 This figure shows locations at which 4 members of a coyote pack were observed around Blacktail Butte in the Grand Teton National Park, outside of Jackson, Wyoming [see Figure 3 and (29)]. The existence of abundant food that was clumped and economically defendable favored the formation of a stable pack in this area of the park for at least 7 years, during which there was significant overlap by pack members in the use of their group-defended territory (29). The 4 polygons shown encompass $25 \%, 50 \%, 75 \%$ and $95 \%$ of all locations. Area is measured in $\mathrm{km}^{2}$. Only pack members defended territorial boundaries, and the size of their territory was much smaller than the home ranges of coyotes living either as mated pairs or alone. The $\Varangle$ was the common observation point.

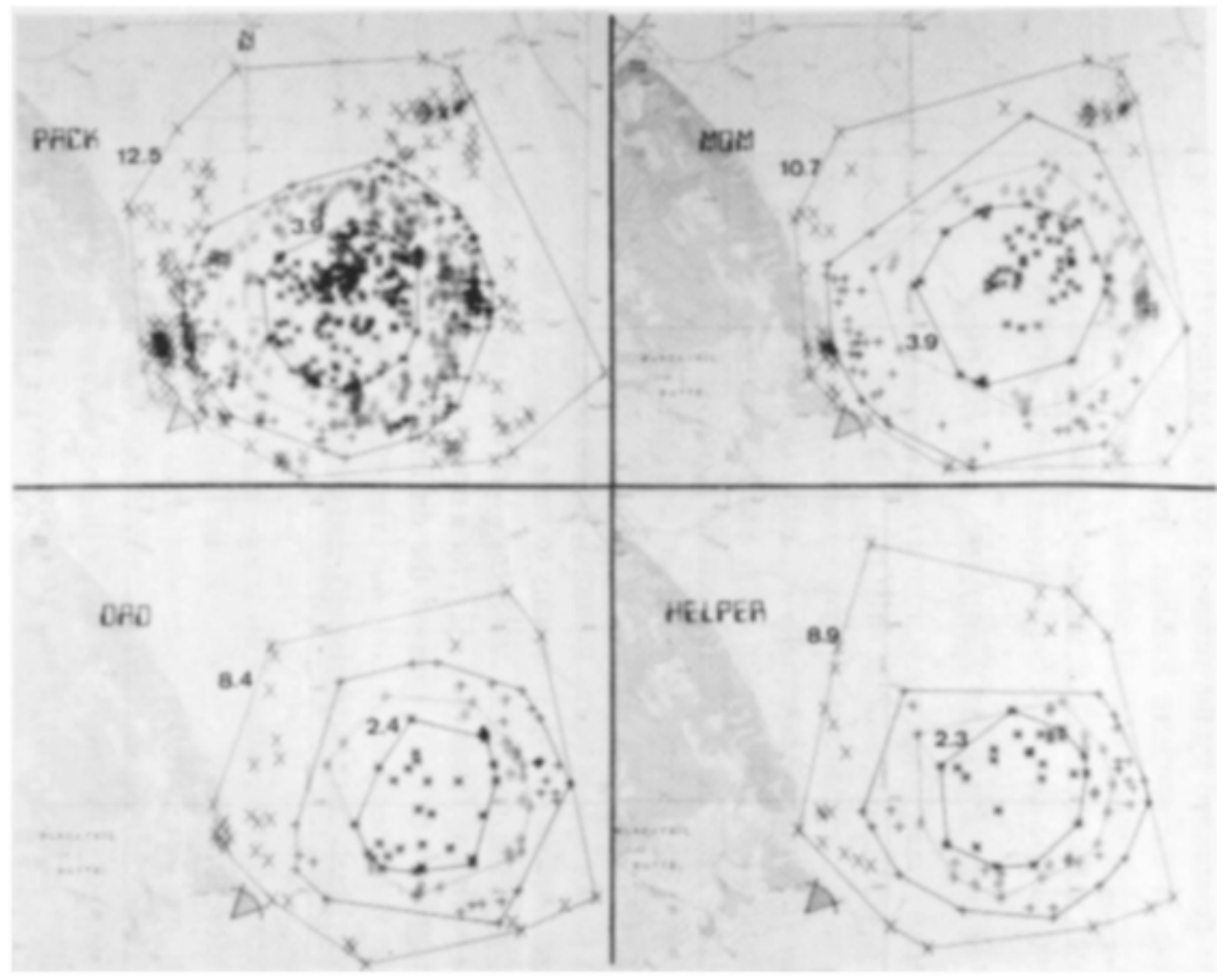

Group and territorial sizes can also vary independently. Range size and configuration may be determined by the pattern of dispersion of food resources (and the influence of topography on the economics of defense), while group size may be determined by the richness of food patches (131). For brown hyenas 
living in the southern Kalahari, for example, territorial size was affected by the distribution of food, whereas group size was influenced by the quality of food in the territory (i.e. the size of available carcasses). Thus, both territorial and group size varied but were not correlated (215).

\section{Mating Patterns, Parental Behavior, and Helping}

Mating patterns, care-giving behavior, and food resources are, not surprisingly, closely related to one another $(61,153,249,268,327)$. Here we look specifically at the relationships among resource availability, monogamy (a prolonged association and essentially exclusive mating relationship between one male and a single female; see 327), and helping behavior [alloparental behavior (324), i.e. care (food, protection) provided to young animals by individuals other than parents; (for reviews and comparative data see $29,46,47,49,123,194,195,222,229,231,249,255,257,311)]$.

Although monogamy is rare in mammals [it has been documented in about $3 \%$ of species studied (153)], it appears to have evolved as the predominant mating strategy in the majority of canids for which there are sufficient data (but see 125) but not in any felids $(153,327$; for a review of the available data, see 105). Harrington et al (125) stressed the difficulty of determining mating patterns under field conditions (mainly due to problems with actually observing identified individuals that are copulating), and their cautious approach deserves close attention. In many instances, researchers base their conclusions about mating patterns on circumstantial evidence--e.g. close association of a pair outside of the breeding season, absence of other adults in the pair's home range.

In general, monogamy is associated with increased male parental care $(153,158)$. In addition, monogamy (and possibly helping; see 105, 229, 249) has apparently evolved in environments in which food resources are energetically costly to collect and in species in which the litter size is comparatively large, as in canids $(61,153)$.

Kleiman (153) differentiated between two general types of monogamy facultative and obligate. Facultative monogamy occurs when the necessary resources are thinly and patchily distributed and when only a single member of the opposite sex is available for mating. Paternal care and helping may be lacking. The only carnivore for which facultative monogamy has been described under field conditions is the maned wolf (73).

Obligate monogamy occurs when a single female cannot rear a litter without aid from conspecifics, perhaps because the carrying capacity of the habitat is insufficient to allow more than one female to breed within the same home range at a given time. [Wittenberger \& Tilson (327) de-emphasize the importance of carrying capacity in the development of monogamy.] Although canids (with the possible exception of maned wolves) would be classified as obligately monogamous, the need for care from the father or helpers is probably not essential for successful rearing of young (327). The presence of helpers, and in some cases paternal care, is positively correlated with pup survival in a variety of canids, however, though the relationship is not always statistically significant $(29,194,195,220-222$; see also 223). But, as a result of prey scarcity, pairs may produce more surviving young than do groups with one or more potential helpers; this phenomenon has been observed in wolves (123). In red foxes, if food is scarce, the presence of helpers may temporarily reduce the reproductive success of breeding individuals (305).

A detailed review of helping behavior is beyond the scope of this paper. (Recent summaries can be found in $29,105,106,123,194,195,222,249$, and 255). Kin selection and reciprocity, often working together, account for most instances of helping in carnivores $(29,194,195,222,231,255,257)$. Among canids, helpers frequently are nonbreeding and nondispersing older siblings of the young for which they care, and an individual that previously helped his younger siblings (or half siblings) may be reciprocated in kind if he 
or she later breeds and if the recipients of his or her help have not dispersed (29, 231; see also Figure 3). Helpers and other nondispersing individuals may also inherit part or all of their natal area and subsequently breed there.

\section{CONCLUSIONS}

The diversity of extant carnivores makes them an exemplary group for studying the evolution of life history patterns and social behavior and ecology from a comparative perspective. Although some general explanations of carnivore social ecology appear to have broad applicability, most species have not even been considered in these syntheses. We need to know more about the how's before we flood the market with grandiose theories about the why's (113). Methods of collecting and analyzing data must be carefully considered in interpreting the results of a given study, and comparisons of two or more research projects should be undertaken with caution. Long-term field projects on unexploited populations are needed; researchers and funding agencies need to make the necessary commitments, despite the obvious risks (75), which are far outweighed by the potential rewards.

From a practical point of view, comparative data on social ecology may be as useful for the development of nature reserves (197) as they are in management programs. Furthermore, the study of social carnivores may shed some light on the evolution of human behavior $(150,161,275)$.

\section{ACKNOWLEDGMENTS}

Marc Bekoff thanks the National Science Foundation, the National Institute of Mental Health, the Harry Frank Guggenheim Foundation, the John Simon Guggenheim Memorial Foundation, and the University of Colorado for financial support of his research, and all of the people who have participated in his research programs, especially Michael C. Wells, for their unrelenting efforts. Tom Daniels was supported by a University Fellowship from the University of Colorado (Boulder) and John Gittleman was supported by a Smithsonian Institution Post-Doctoral Fellowship during the preparation of this chapter. Joseph Ortega, Beth Bennett, Joel Berger, John Byers, Douglas Conner, Devra Kleiman, Mark Owens, Delia Owens, and John Seidensticker provided comments on an earlier draft of the manuscript. The Owenses kindly provided unpublished information from their long-term studies on lions and brown hyenas in the central Kalahari. Jan Logan drew Figures 1, 2, and 3 and Muriel Sharp and Bay Roberts helped to compile and organize the references. Mary Marcotte and Jeanie Cavanagh kindly typed numerous color-coded drafts of this paper.

\section{Literature Cited}

1. Albignac, R. 1972. The carnivores of Madagascar. In Biogeography and Ecology of Madagascar, ed. R. Batistina, G. Richard-Vindard, pp. 21-35. The Hague: Junk

2. Albignac, R. 1973. Mammiferes carnivores. Faune de Madagascar. No. 36. 206 pp.

3. Alexander. R. D. 1974. The evolution of social behavior. Ann. Rev. Ecol. Syst. 5:325-83.

4. Allen, D. 1979. Wolves of Minong: Their Vital Role in a Wild Community. Boston: Houghton-Mifflin. $499 \mathrm{pp}$.

5. Altmann, J. 1974. Observational study of behavior. Behaviour 49:227-67

6. Altmann, S. A., Altmann, J. 1979. Demographic constraints on behavior and social organization. In Primate Ecology and Human Origins, ed. I. S. Bernstein, E. O Smith, pp. 47-63. New York: Garland. 362 pp.

7. Amlaner, C. J., Macdonald, D. W., eels. 1980. A Handbook on Biotelemetry and Radio Tracking. Oxford: Pergamon

8. Armitage, K. B. 1981. Sociality as a life-history tactic of ground squirrels. Oecologia 48:36-49 
9. Armitage, K. B. 1982. Social dynamics of juvenile marmots: Role of kinship and individual variability. Behav. Ecol. Sociobiol. 11:33-36

10. Ballard, W. B., Miller, S.D., Spraker. T. H. 1982. Home range, daily movements and reproductive biology of brown bear in southcentral Alaska. Can. Field. Nat. 96:1-5

11. Balph, D. F. Innis, G. S., Balph. M. H. 1980. Kin selection in Rio Grande turkeys: A critical assessment. Auk 97:854-60

12. Bearder, S. K. 1975. Inter-relationship between hyaenas and their competitors in the Transvaal lowveld. Publ. Univ. Pretoria 97:39-49

13. Bekoff, M. 1974. Social play and play-soliciting by infant canids. Am. Zool. 14:323-40

14. Bekoff, M. 1977. Quantitative studies of three areas of classical ethology: Social dominance, behavioral taxonomy, and behavioral variability. See Ref. 127, pp. 1-46

15. Bekoff, M. 1977. Mammalian dispersal and the ontogeny of individual behavioral phenotypes. Am. Nat. 111:715-32

16. Bekoff, M., ed. 1978. Coyotes: Biology, Behavior, and Management. New York: Academic. 384 pp.

17. Bekoff, M. 1978. Behavioral development in coyotes and eastern coyotes. See Ref. 16, pp. 97-126

18. Bekoff, M. 1978. A field study of the development of behavior in Adelie penguins: Univariate and numerical taxonomic approaches. In The Development of Behavior: Comparative and Evolutionary Aspects, ed. G. Burghardt, M. Bekoff, pp. 177-202. New York: Garland. 429 pp.

19. Bekoff, M. 1981. Vole population cycles: Kin selection or familiarity? Oecologia 48:131

20. Bekoff, M. 1981. Mammalian sibling interactions: Genes, facilitative environments, and the coefficient of familiarity. In Parental Care in Mammals, ed. D. J. Gubernick, P. H. Klopfer, pp. 30746. New York: Plenum. 459 pp.

21. Bekoff, M. 1984. Social play behavior. BioScience 34:228-33

22. Bekoff, M., Byers, J. A. 1981. A critical reanalysis of the ontogeny and phylogeny of mammalian social and locomotor play: An ethological hornet's nest. In Behavioral Development: The Bielefeld Interdisciplinary Conference, ed. K. Immelmann, G. W. Barlow, L. Petrinovich, M. Main, pp. 296-337. New York: Cambridge Univ. Press. 754 pp.

23. Bekoff, M., Byers, J. A. 1985. The development of behavior from evolutionary and ecological perspectives. Evol. Bioi. 19: In press

24. Bekoff, M., Diamond, J., Mitton, J. B. 1981. Life history patterns and sociality in canids: Body size, reproduction, and behavior. Oecologia 50:388-90

25. Bekoff, M., Hill, H. L., Mitton, J. B. 1975. Behavioral taxonomy in canids by discriminant function analysis. Science 190: 1223-25

26. Bekoff, M., Mech, L. D. 1984. Simulation analyses of space use: Home range estimates, variability, and sample size. Behav. Res. Methods Instrum. Comput. 16:32-37

27. Bekoff, M., Wells, M. C. 1980. The social ecology of coyotes. Sci. Am. 242: 130-48

28. Bekoff, M., Wells, M. C. 1981. Behavioural budgeting by wild coyotes: The influence of food resources and social organization. Anim. Behav. 29:794-801

29. Bekoff, M., Wells, M. C. 1982. Behavioral ecology of coyotes: Social organization, rearing patterns, space use, and resource defense. Z. Tierpsychol. 60: 281-305

30. Bekoff, M., Wieland, C., Lavender, W. A. 1982. Space-Out: Graphics programs to study and to simulate space use and movement patterns. Behav. Res. Methods Instrum. 14:34-36

31. Berger, J. 1979. Social ontogeny and behavioural diversity: Consequences for Bighorn sheep Ovis canadensis inhabiting desert and mountain environments. J. Zool. 118:251-66

32. Bertram, B. C. R. 1973. Lion population regulation. EastAfr. Wildl. J. 11:215-25

33. Bertram, B. C. R. 1975. The social system of lions. Sci. Am. 232:54-65

34. Bertram, B. C. R. 1976. Kin selection in lions and in evolution. In Growing Points in Ethology, ed. P. P. G. Bateson, R. A. Hinde, pp. 281-301. New York: Cambridge Univ. Press

35. Bertram, B. C. R. 1978. Pride of Lions. New York: Scribner's 
36. Bertram, B. C. R. 1978. Living in groups: Predators and prey. In Behavioural Ecology: An Evolutionary Approach, ed. J. R. Krebs, N. B. Davies, pp. 64-96. Sunderland, Mass: Sinauer. 494 pp.

37. Bertram, B. C. R. 1979. Serengeti predators and their social systems. In Serengeti: Dynamics of an Ecosystem, ed. A. R. E. Sinclair, M. Norton-Griffiths, pp. 221-48. Chicago: Univ. Chicago. 389 pp.

38. Biben, M. 1983. Comparative social ontogeny of social behaviour in three South American canids, the maned wolf, crab-eating fox and bush dog: Implications for sociality. Anim. Behav. 31:814-26

39. Boorman, S. A., Levitt, P.R. 1980. The Genetics of Altruism. New York: Academic. 459 pp.

40. Bothma, J. du. 1971. Food of Canis mesomelas in South Africa. Ann. Transvaal Mus. 27:15-26

41. Bowen, W. D. 1981. Variation in coyote social organization: The influence of prey size. Can. J. Zool. 59:639-52

42. Bradbury, J. W., Vehrencamp, S. L. 1976. Social organization and foraging in Emballonurid bats. I. Field studies; II. A model for the determination of group size. Behav. Ecol. Sociohiol. 1:337-81; 383404

43. Brand, C. J., Keith, L. B. 1979. Lynx demography during a snowshoe hare decline in Alberta. J. Wildl. Manage. 43:27-48

44. Brown, J. L. 1964. The evolution of diversity of avian territorial systems. Wilson Bull. 76:160--69

45. Brown, J. L. 1974. Alternate routes to sociality in jays-with a theory for the evolution of altruism and communal breeding. Am. Zool. 14:63-80

46. Brown, J. L. 1978. Avian communal breeding systems. Ann. Rev. Ecol. Syst. 9:123-55

47. Brown, J. L. 1980. Fitness in complex avian social systems. In Evolution of Social Behavior: Hypotheses and Empirical Tests, ed. H. Markl, pp. 115-28. Weinheim, West Germany: Chemie. 253 pp.

48. Brown, J. L. 1982. Optimal group size in territorial animals. J. Theor. Biol. 95:793-810

49. Brown, J. L. 1983. Cooperation-a biologist's dilemma. Adv. Study Behav. 13:1-37

50. Bygott, J.D., Bertram, B. C. R., Hanby, J. P. 1979. Male lions in large coalitions gain reproductive advantage. Nature 26:839-41

51. Calder, W. A. III. 1983. Ecological scaling: Mammals and birds. Ann. Rev. Ecol. Syst. 14:213-30

52. Camenzind, F. J. 1978. Behavioral ecology of coyotes on the National Elk Refuge, Jackson, Wyoming. See Ref. 16, pp. 267-94

53. Caraco, T., Wolf, L. L. 1975. Ecological determinants of group sizes of foraging lions. Am. Nat. 109:343-52

54. Chapman, J. W., Feldhamer, G. A., eds. 1982. Wild Mammals of North America: Biology, Management, and Economics. Baltimore: Johns Hopkins Univ. Press. 1147 pp.

55. Chapman, R. C. 1978. Rabies: Decimation of a wolf pack in arctic Alaska. Science 201:365-67

56. Charlesworth, B. 1980. Evolution in Age-Structured Populations. Cambridge: Cambridge Univ. Press. 300 pp.

57. Chase, I. D. 1974. Models of hierarchy formation in animal societies. Behav. Sci. 19:374-82

58. Chase, I. D. 1980. Cooperative and noncooperative behavior in animals. Am. Nat. 115:827-57

59. Cheeseman, C. L., Milson, R. B., eds. 1982. Telemetric studies of vertebrates. Symp. Zool. Soc. London 49:1-368

60. Chiarelli, A. B. 1975. The chromosomes of the Canidae. See Ref. 97, pp. 40-53

61. Clutton-Brock, T. H., Harvey, P. H. 1978. Mammals, resources and reproductive strategies. Nature 17:191-95

62. Clutton-Brock, T. H., Harvey, P. H. 1979. Comparison and adaptation. Proc. R. Soc. London Ser. B 205:547-65

63. Clutton-Brock, T. H., Harvey, P. H. 1983. The functional significance of variation in body size among mammals. See Ref. 84, pp. 632-63 
64. Clutton-Brock, T. H., Harvey, P. H. 1984. Comparative approaches to investigating adaptation. In Behavioural Ecology: An Evolutionary Approach, ed. J. R. Krebs, N. B. Davies, pp. 7-29. Oxford: Blackwell

65. Colgan, P., Ed. 1978. Quantitative Ethology. New York: Wiley. 364 pp.

66. Craighead, F. C. Jr. 1979. The Track of the Grizzly. San Francisco: Sierra Club. 261 pp.

67. Craighead, J. J., Mitchell, J. A. 1982. Grizzly bear. See Ref. 54, pp. 515-56

68. Crook, J. H. 1964. The evolution of social organization and visual communication in the weaver birds (Ploceinae). Behaviour Suppl. 10:1-78

69. Crook, J. H., Ellis, J. E., Goss-Custard, J. D. 1976. Mammalian social system: Structure and function. Anim. Behav. 24:261-74

70. Curio, E. 1976. The Ethology of Predation. New York: Springer-Verlag. 250 pp.

71. Dagg, A. I. 1983. Harems and Other Horrors: Sexual Bias in Behavioral Biology. Waterloo, Canada: Otter. 125 pp.

72. Deutsch, L. A. 1983. An encounter between bush dog (Speothos venaticus) and paca (Agouti paca). J. Mammal. 64:532-33

73. Dietz, J. M. 1984. Ecology and social organization of the maned wolf (Chrysocyon brachyurus), Smithson. Contrib. Zool. No. 392

74. Don, B. A. C., Rennolls, K. 1983. A home range model incorporating biological attraction points. J. Anim. Ecol. 52:69-81

75. Dunbar, R.I. M. 1983. Social systems as optimal strategy sets. In Environment and Population: Problems of Adaptation, ed. J. B. Calhoun, pp. 4-6. New York: Praeger Sci.

76. Dunn, J. E. 1979. A complete test for dynamic territorial interaction. Proc. 2nd Int. Conf. Wildl. Biotelem., Laramie, Wyo., pp. 159-69

77. Eaton, R. L. 1973. The World's Cats: Ecology and Conservation. Seattle: Feline Res. Group. 349 pp.

78. Eaton, R. L. 1974. The World's Cats: Biology, Behavior and Management of Reproduction. Seattle: Feline Res. Group. 260 pp.

79. Eaton, R. L. 1976. The World's Cats: Contributions to Biology, Ecology, Behavior and Evolution. Seattle: Carnivore Res. Inst. 179 pp.

80. Eaton, R. L. 1977. The World's Cats: Contributions to Breeding Biology, Behavior and Husbandry. Seattle: Carnivore Res. Inst. 144 pp.

81. Eisenberg, J. F. 1966. The social organization of mammals. Handb. Zool. VIII (10/7). Berlin: De Gruyter

82. Eisenberg, J. F. 1977. Comments. In The Biology and Conservation of the Callitrichidae, ed. D. G. Kleiman, pp. 220. Washington DC: Smithsonian Inst. 354 pp.

83. Eisenberg, J. F. 1981. The Mammalian Radiations: An Analysis of Trends in Evolution, Adaptation, and Behavior. Chicago: Univ. Chicago Press. 610 pp.

84. Eisenberg, J. F., Kleiman, D. G., eds. 1983. Advances in the study of mammalian behavior. Am. Soc. Mammal., Spec. Publ. No. 7. 753 pp.

85. Eisenberg, J. F., Leyhausen, P. 1972. The phylogenesis of predatory behavior in mammals. Z. Tierpsychol. 30:59-93

86. Eisenberg, J. F., Muckenhirn, N. A., Rudran, R. 1972. The relation between ecology and social structure in primates. Science 176:863-73

87. Elliott, J.P., McT. Cowan, I. 1978. Territoriality, density, and prey of the lion in Ngorongoro Crater, Tanzania. Can. J. Zool. 56:1726-34

88. Englund, J. 1980. Population dynamics of the red fox (Vulpes vulpes L., 1758) in Sweden. See Ref. 331, pp. 107-21

89. Erlinge, S. 1974. Distribution, territoriality and numbers of the weasel Mustela nivalis in relation to prey abundance. Oikos 25:308-14 
90. Erlinge, S. 1977. Spacing strategy in stoat Mustela erminea. Oikos 28:32-42

91. Estes, R. D., Goddard, J. 1967. Prey selection and hunting behavior of the African wild dog. J. Wildl. Manage. 31:52-70

92. Ewer, R. F. 1968. Ethology of Mammals. New York: Plenum. 418 pp.

93. Ewer, R. F. 1973. The Carnivores. New York: Cornell Univ. Press. 494 pp.

94. Fagen, R. 1981. Animal Play Behavior. Oxford: Oxford Univ. Press. 684 pp.

95. Ferguson, J. W. H., Nel, J. A. J., de Wett, M. J. 1983. Social organization and movement patterns of black-backed jackals Canis mesomelas in South Africa. J. Zool. 199:487-502

96. Fisler, G. F. 1969. Mammalian organizational systems. Nat. Hist. Mus. Los Angeles Cty. Sci. Bull. 167:1-32

97. Fox, M. W., ed. 1975. The Wild Canids. New York: Van Nostrand-Reinhold. 508 pp.

98. Fox, M. W., Lockwood, R., Shideler, R. 1974. Introduction studies in captive wolves. Z. Tierpsychol. 35:38-48

99. Frame, L. H., Frame, G. W. 1976. Female African wild dogs emigrate. Nature 263:227-29

100. Frame, L. H., Malcolm, J. R., Frame, G. W., van Lawick, H. 1979. Social organization of African wild dogs (Lycaon pictus) on the Serengeti Plains, Tanzania 1967-1978. Z. Tierpsychol. 50:225-49

101. Fritts, S. H., Mech, L. D. 1981. Dynamics, movements, and feeding ecology of a newly protected wolf population in northwestern Minnesota. Wildl. Monogr. 80:1-79

102. Fritzell, E. K. 1978. Habitat use by prairie raccoons during the waterfowl breeding season. J. Wildt. Manage. 42:118-27

103. Fuentes, E. R., Jaksic, F. M. 1979. Latitudinal size variation of Chilean foxes: Tests of alternative hypotheses. Ecology 60:43-47

104. Gaines, M. S., McClenaghan, L. R. 1980. Dispersal in small mammals. Ann. Rev. Ecol. Syst. II :163-96

105. Gittleman, J. L. 1984. The behavioural ecology of carnivores. PhD thesis. Univ. Sussex, Brighton, England

106. Gittleman, J. L. 1984. Functions of communal care in mammals. In Evolution: Essays in Honour of John Maynard Smith, ed. P. J. Greenwood, M. Slatkin. Cambridge: Cambridge Univ. Press. In press

107. Gittleman, J. L., Harvey, P. H. 1982. Carnivore home-range size, metabolic needs and ecology. Behav. Ecol. Sociobiol. 10:57-63

108. Golightly, R. 1981. The comparative energetics of two desert canids: The coyote (Canis latrans) and the kit fox (Vulpes macrotis). PhD thesis. Ariz. State Univ., Tempe, Ariz.

109. Good, I. J. 1983. The philosophy of exploratory data analysis. Philos. Sci. 50:283-95

110. Gorman, M. L. 1979. Dispersion and foraging of the small Indian mongoose, Herpestes auropunctatus (Carnivora: Viverridae) relative to the evolution of social viverrids. J. Zoot. 187:65-73

111. Gosling, L. M., Petrie, M. 1981. The economics of social organization. In Physiological Ecology: An Evolutionary Approach, ed. C. R. Townsend, P. Calow, pp. 315-45. Oxford: Blackwell

112. Gould, S. J. 1977. Ontogeny and Phylogeny. Cambridge, Mass: Harvard Univ. Press. 501 pp.

113. Gould, S. J. 1983. Genes on the brain. NY Rev. Books 30(11):5-10

113a. Gould, S. J., Lewontin, R. C. 1979. The spandrels of San Marco and the panglossian paradigm: A critique of the adaptationist programme. Proc. R. Soc. London Ser. B 205:581-98

114. Greenwood, P. J. 1980. Mating systems, philopatry and dispersal in birds and mammals. Anim. Behav. 28:1140-62

115. Greenwood, R. J. 1982. Nocturnal activity and foraging of prairie raccoons (Procyon lotor) in North Dakota. Am. Midi. Nat. 107:238-43

116. Guggisberg, C. A. W. 1975. Wild Cats of the World. New York: Taplinger

117. Haldane, J. B. S. 1956. On being the right size. In The World of Mathematics, ed. J. R. Newman, pp. 952-57. New York: Simon \& Schuster 
118. Hamilton, W. D. 1963. The evolution of altruistic behavior. Am. Nat. 97:354-56

119. Hamilton, W. D. 1964. The genetical evolution of social behaviour. I and II. J. Theor. Bioi. 7:1-52

120. Hanby, J. P., Bygott, J. D. 1979. Population changes in lions and other predators. In Serengeti: Dynamics of an Ecosystem, ed. A. R. E. Sinclair, M. Norton-Griffiths, pp. 249-62. Chicago: Univ. Chicago Press. 389 pp.

121. Happold, M. 1976. The ontogeny of social behaviour in four conilurine rodents (Muridae) of Australia. Z. Tierpsychol. 40:265-78

122. Harcourt, A. H., Stewart, K. J. 1981. Gorilla male relationships: Can differences during immaturity lead to contrasting reproductive tactics in adulthood? Anim. Behav. 29:206-10

123. Harrington, F. H., Mech, L. D., Fritts, S. H. 1983. Pack size and wolf pup survival: Their relationship under varying ecological conditions. Behav. Ecol. Sociobiol. 13:19-26

124. Harrington, F. H., Pacquet, P. C., eds. 1982. Wolves of the World: Perspectives of Behavior, Ecology, and Conservation. Park Ridge, NJ: Noyes. 474 pp.

125. Harrington, F. H., Pacquet, P. C., Ryon, J., Fentress, J. C. 1982. Monogamy in wolves: A review of the evidence. See Ref. 124, pp. 209-22

126. Harvey, P. H., Mace, G. M. 1982. Comparisons between taxa and adaptive trends: Problems of methodology. In Current Problems in Sociobiology, ed. King's Coli. Sociobiol. Group, pp. 343-61. Cambridge: Cambridge Univ. Press. 394 pp.

127. Hazlett, B. A., ed. 1977. Quantitative Methods in the Study of Animal Behavior. New York: Academic. $222 \mathrm{pp}$.

128. Hennemann, W. W., Thompson, S.D., Konecky, M. J. 1983. Metabolism of crab-eating foxes, Cerdocyon thous: Ecological influences on the energetics of canids. Physiol. Zool. 56:319-24

129. Herrero, S. 1972. Aspects of evolution and adaptation in American black bears (Ursus americanus Pallus) and brown and grizzly bears (Ursus arctos Linn.) of North America. In Bears-Their Biology and Management, IUCN Publ. No. 23, pp. 221-31. Morges. Switzerland: Int. Union Conserv. Nat. \& Nat. Res. (IUCN)

130. Herrero, S. 1978. A comparison of some features of the evolution, ecology and behavior of black and grizzly/brown bears. Carnivore 1:7-17

131. Hersteinsson, P .. Macdonald, D. W. 1982. Some comparisons between red and arctic foxes, Vulpes vulpes and Alopex lagopus, as revealed by radio tracking. Symp. Zool. Soc. London 49: 259-89

132. Hilborn, R., Stearns, S. C. 1982. On inference in ecology and evolutionary biology: The problem of multiple causes. Acta Biotheor. 31:145-64

133. Hinde, R. A. 1970. Animal Behaviour. New York: McGraw-Hill. 876 pp.

134. Hinde, R. A. 1974. Biological Bases of Human Social Behaviour. New York: McGraw-Hill. 462 pp.

135. Hinton, H., Dunn, A. 1967. Mongooses: Their Natural History and Behavior. London: Oliver \& Boyd. $144 \mathrm{pp}$.

136. Hughes, A. L. 1983. Kin selection of complex behavioral strategies. Am. Nat. 122:181-90

137. Ikeda, H., Ono, Y., Baba, M., Doi, T., Iwamoto, T. 1982. Ranging and activity patterns of three nocturnal viverrids in Omo National Park, Ethopia. Afr. J. Ecol. 20:179-86

138. Izawa, M., Doi, T., Ono, Y. 1982. Grouping patterns of feral cats (Felis catus) living on a small island in Japan. Jpn. J. Ecol. Nippon Seitai Gakkaishi 32:373-82

139. Jaksic, F. M., Schlatter, R. P., Yanez, J. L. 1980. Feeding ecology of central Chilean foxes, Dusicyon culpaeus and Dusicyon grise us. J. Mammal. 61:254-60

140. Jerison, H. J. 1973. Evolution of the Brain and Intelligence. New York: Academic

141. Johnsingh, A. J. T. 1982. Reproductive and social behaviour of the dhole, Cuon alpinus (Canidae). J. Zool. 198:443-63

142. Jonkel, C. J., McTaggart Cowan, I. 1971. The black bear in the spruce-fir forest. Wildl. Monogr. 27:1-57 
143. Kaufmann, J. H. 1962. Ecology and social behavior of the coati, Nasua nasua, on Barro Colorado Island, Panama. Univ. Calif. Berkeley Publ. Zoo!. 60:95-222

144. Kaufmann, J. H. 1982. Raccoon and allies. See Ref. 54, pp. 567-85

145. Kavanagh, M. 1981. Variable territory among Tantalus monkeys in Cameroon. Folia Primatol. 36:7.6-98

146. Kenyon, K. W. 1969. The sea otter in the eastern Pacific. North Am. Fauna 68:1-352

147. Kenyon, K. W. 1982. Sea otter. See Ref. 54, pp. 704-10

148. Kihlström, J. E. 1972. Period of gestation and body weight in some placental mammals. Comp. Biochem. Physiol. 43:674-79

149. King, C. M. 1975. The home range of the weasel (Mustela nivalis) in an English woodland. J. Anim. Ecol. 44:639-68

150. King, G. E. 1980. Alternative uses of primates and carnivores in the reconstruction of early hominid behavior. Ethology Sociobiol. 1:99-109

151. King, J. A. 1973. The ecology of aggressive behavior. Ann. Rev. Ecol. Syst. 4:117-38

152. Kingdon, J. 1977. East African Mammals. Vol. 3A, Carnivores. New York: Academic

153. Kleiman, D. G. 1977. Monogamy in mammals. Q. Rev. Bioi. 52:39-69

154. Kleiman, D. G. 1979. Parent-offspring conflict and sibling competition in a monogamous primate. Am. Nat. 114: 753-59

155. Kleiman, D. G. 1983. Ethology and reproduction of captive giant pandas (Ailuropoda melanoleuca). Z. Tierpsychol. 62:1-46

156. Kleiman, D. G., Brady, C. A. 1978. Coyote behavior in the context of recent canid research: Problems and perspectives. See Ref. 16, pp. 163-88

157. Kleiman, D. G., Eisenberg, J. F. 1973. Comparisons of canid and felid social systems from an evolutionary perspective. Anim. Behav. 21:637-59

158. Kleiman, D. G., Malcolm, J. 1981. The evolution of male parental investment in mammals. In Parental Care in Mammals, eds. D. J. Gubernick, P. H. Klopfer, pp. 347-87. New York: Plenum

159. Klinghammer, E., ed. 1979. The Behavior and Ecology of Wolves. New York: Garland. 588 pp.

160. Koop, K., Velimirov, B. 1982. Field observations on activity and feeding of bat-eared foxes (Otocyon megalotis) at Nxai Pan, Botswana. Afr. J. Ecol. 20:23-27

161. Kruuk, H. 1972. The Spotted Hyena. Chicago: Univ. Chicago Press. 335 pp.

162. Kruuk, H. 1975. Functional aspects of social hunting by carnivores. In Function and Evolution in Behaviour: Essays in Honour of Professor Niko Tinbergen, ed. G. Baerends, C. Beer, A. Manning, pp. 119-41. New York: Oxford Univ. Press. 393 pp.

163. Kruuk, H. 1976. Feeding and social behaviour of the striped hyaena (Hyaena vulgaris Desmarest). East Afr. Wildl. J. 14:91-111

164. Kruuk, H. 1978. Foraging and spatial organisation of the European badger, Meles meles L. Behav. Ecol. Sociobiol. 4:75-89

165. Kruuk, H., Parish, T. 1981. Feeding specialization of the European badger (Meles meles). J. Anim. Ecol. 50:773-88

166. Kruuk, H., Sands, W. A. 1972. The aardwolf (Proteles cristatus Sparrman 1783) as a predator of termites. East Afr. Wildl. J. 10:211-27

167. Kruuk, H., Turner, M. 1967. Comparative notes on predation by lion, leopard, cheetah and wild dog in the Serengeti area, East Africa. Mammalia 31:1-27

168. Kurten, B. 1971. The Age of Mammals. New York: Columbia Univ. Press

169. Lamprecht, J. 1978. The relationship between food competition and foraging group size in some larger carnivores. Z. Tierpsychol. 46:337-43

170. Lamprecht, J. 1978. On diet, foraging behaviour and interspecific food competition of jackals in the Serengeti National Park, East Africa. Z. Saeugetierk. 43:210--23 
171. Lamprecht, J. 1979. Field observations on the behaviour and social system of the bat-eared fox, Otocyon megalotis Desmarest. Z. Tierpsychol. 49:260--84

172. Lamprecht, J. 1981. The function of social hunting in larger terrestrial carnivores. Mammal Rev. 11:169-79

173. Latour, P. B. 1981. Interactions between free-ranging, adult male polar bears (Ursus maritimus Phipps): A case of adult social play. Can. J. Zool. 59:1775-83

174. Latour, P. B. 1981. Spatial relationships and behavior of polar bears (Ursus maritimus Phipps) concentrated on land during the ice-free season of Hudson Bay. Can. J. Zool. 59:1763-74

175. Laundre, J. W., Keller, B. L. 1984. Home range of coyotes: A critical review. J. Wildl. Manage. 48:127-39

176. Lawton, J. 1979. A sociobiologist's new testament? Nature 278:193-94

177. Lecount, A. L. 1982. Characteristics of a central Arizona black bear population. J. Wildl. Manage. 46:861-68

178. Lehner, P. N. 1979. Handbook of Ethological Methods. New York: Garland. 403 pp.

179. Leitch, I., Hytten, F. E., Billewicz, W. Z. 1959. The maternal and neonatal weights of some Mammalia. Proc. Zool. Soc. London 13:11-28

180. Leutenegger, W. 1976. Allometry of neonatal size in eutherian mammals. Nature 263:229-30

181. Leyhausen, P. 1965. The communal organization of solitary mammals. Symp. Zool. Soc. London 14:249-63

182. Leyhausen, P. 1979. Cat Behavior: The Predatory and Social Behavior of Domestic and Wild Cats. New York: Garland. 340 pp.

183. Liberg, O. 1980. Spacing patterns in a population of free roaming domestic cats. Oikos 35:336-49

184. Lindeque, M., Skinner, J. D. 1982. A seasonal breeding in the spotted hyena (Crocuta crocuta Erxleben), in Southern Africa. Afr. J. Ecol. 20:271-78

185. Lindstrom, E. 1982. Population ecology of the redfox (Vulpes vulpes L.) in relation to food supply. $\mathrm{PhD}$ thesis. Univ. Stockholm, Stockholm, Sweden

186. Lloyd, H. G. 1980. The Red Fox. London: Batsford. 320 pp.

187. Lloyd, H. G. 1980. Habitat requirements of the red fox. See Ref. 331, pp. 7-25

188. Lott, D. F., Minta, S.C. 1983. Random individual association and social group instability in American bison (Bison bison). Z. Tierpsychol. 61:153-72

189. Macdonald, D. W. 1978. Observations on the behaviour and ecology of the striped hyaena, Hyaena hyaena, in Israel. Isr. J. Zool. 27:189-98

190. Macdonald, D. W. 1979. The flexible social system of the golden jackal, Canis aureus. Behav. Ecol. Sociobiol. 5:17-38

191. Macdonald, D. W. 1980. Rabies and Wildlife: A Biologist's Perspective. New York: Oxford Univ. Press. $151 \mathrm{pp}$.

192. Macdonald, D. W. 1980. Social factors affecting reproduction amongst red foxes (Vulpes vulpes L., 1758). See Ref. 331, pp. 123-75

193. Macdonald, D. W. 1983. The ecology of carnivore social behaviour. Nature 301:379-84

194. Macdonald, D. W., Moehlman, P. D. 1982. Cooperation, altruism, and restraint in the reproduction of.carnivores. Perspect. Ethology 5:433-67

195. Malcolm, J., Marten, K. 1982. Natural selection and the communal rearing of pups in African wild dogs (Lycaon pictus). Behav. Ecol. Sociobiol. 10:1-13

196. Maloiy, G. M. O., Kamau, J. M. Z., Shkolnik, A., Meir, M., Arieli, R. 1982. Thermoregulation and metabolism in a small desert carnivore: The fennec fox (Fennecus zerda) (Mammalia). J. Zool. 198:279-91

197. Margules, C., Higgs, A. J., Rafe, R. W. 1982. Modern biogeographic theory: Are there any lessons for nature reserve design? Biol. Conserv. 24:115-28

198. Matthews, W. D. 1930. The phylogeny of dogs. J. Mammal. 11:117-38 
199. Maurel, D., Boissin, J. 1983. Comparative mechanisms of physiological, metabolical and ecoethological adaptation to the winter season in two wild European mammals: The European badger (Meles meles L.) and the red fox (Vulpes vulpes L.). In Plant, Animal, and Microbial Adaptations to Terrestrial Environments, ed. N. S. Magaris, M. Arianoutsou-Faraggitaki, R. J. Reiter, pp. 219-33. New York: Plenum

200. Maynard Smith, J. 1982. The evolution of social behavior--a classification of models. In Current Problems in Sociobiology, ed. King's Coli. Sociobiol. Group, pp. 29--44. New York: Cambridge Univ. Press. 394 pp.

201. McBride, G. 1976. The study of social organizations. Behaviour 59:96-115

202. McNab, B. K. 1980. Food habits, energetics, and the population biology of mammals. Am. Nat. 116:106-24

203. McNab, B. K. 1983. Ecological and behavioral consequences of adaptation to various food resources. See Ref. 84, pp. 664--95

204. Mech, L. D. 1970. The Wolf: The Ecology and Behavior of an Endangered Species. New York: Doubleday. 384 pp.

205. Mech, L. D. 1977. Population trend and winter deer consumption in a Minnesota wolf pack. In Proc. 1975 Predator Symp., ed. R. L. Phillips, C. Jonkel, pp. 55-83. Missoula: Univ. Mont. Press

206. Mech, L. D. 1977. Productivity, mortality, and population trends of wolves in northeastern Minnesota. J. Mammal. 58:559-74

207. Mech, L. D. 1983. Handbook of Animal Radio-Tracking. Minneapolis: Univ. Minn. Press. 107 pp.

208. Melemis, S.M., Falls, J. B. 1982. The defense function: A measure of territorial behaviour. Can. J. Zool. 60:495-501

209. Michener, G. R. 1983. Kin identification, matriarchies, and the evolution of sociality in grounddwelling sciurids. See Ref. 84, pp. 528-72

210. Millar, J. S. 1977. Adaptive features of mammalian reproduction. Evolution 31:370-86

211. Millar, J. S. 1981. Pre-partum reproductive characteristics of eutherian mammals. Evolution 35:1149-63

212. Mills, M. G. L. 1978. Foraging behaviour of the brown hyaena (Hyaena brunnea Thinberg, 1820) in the southern Kalahari. Z. Tierpsychol. 48:113--41

213. Mills, M.G. L. 1978. The comparative socio-ecology of the hyaenidae. Carnivore 1:1-7

214. Mills, M.G. L. 1982. The mating system of the brown hyaena, Hyaena brunnea, in the southern Kalahari. Behav. Ecol. Sociobiol. 10: 131-36

215. Mills, M. G. L. 1982. Factors affecting group size and territory size of the brown hyaena, Hyaena brunnea, in the southern Kalahari. J. Zool. 198:39-51

216. Mills, M. G. L. 1983. Behavioural mechanisms and group maintenance of the brown hyaena, Hyaena brunnea, in the southern Kalahari. Anim. Behav. 31:503-10

217. Mills, M. G. L. 1983. Mating and denning behaviour of the brown hyaena Hyaena brunnea and comparisons with other hyaenidae. Z. Tierpsychol. 64:331-42

218. Mills, M.G. L., Gorman, M. L., Mills, M. E. J. 1980. The scent marking behavior of the brown hyaena, Hyaena brunnea. S. Afr. J. Zool. 15:240-48

219. Mitani, J. C., Rodman, P. S. 1979. Territoriality: The relation of ranging pattern and home range size to defendability, with an analysis of territoriality among primate species. Behav. Ecol. Sociobiol. 5:241-51

220. Moehlman, P. D. 1979. Jackal helpers and pup survival. Nature 277:382-83

221. Moehlman, P. D. 1981. Reply to Montgomerie. Nature 289:825

222. Moehlman, P. D. 1983. Socioecology of silverbacked and golden jackals (Canis mesomelas and Canis aureus.) See Ref. 84, pp. 423-53

223. Montgomerie, R. D. 1981. Why do jackals help their parents? Nature 289:824-25

223a. Moore, J., Ali, R. 1984. Are dispersal and inbreeding avoidance related? Anim. Behav. 32:94-112 
224. Myers, N. 1977. The cheetah's relationships to the spotted hyena: Some implications for a threatened species. See Ref. 205. pp. 191-200.

225. Novick, H. J., Stewart, G. R. 1982. Home range and habitat preferences of black bears in the San Bernardino mountains of Southern California. Calif. Fish Game 68:21-35

226. Nowak, R. M. 1978. Evolution and taxonomy of coyotes and related Canis. See Ref. 16, pp. 3-15

227. Nowak, R. M., Paradiso, J. L. 1983. Walker's Mammals of the World. Baltimore: Johns Hopkins Univ. Press. 4th ed.

228. Nudds, T. D. 1978. Convergence of group size strategies by mammalian social carnivores. Am. Nat. 112:957-60

229. Owens, D. D., Owens, M. J. 1979. Communal denning and clan associations in brown hyenas (Hyaena brunnea Thunberg) of the central Kalahari Desert. Afr. J. Ecol. 17:35-44

230. Owens, D. D., Owens, M. J. 1979. Notes on social organization and behavior in brown hyenas (Hyaena brunnea). J. Mammal. 60:405-8

231. Owens, D. D., Owens, M. J. 1984. Helping behavior in brown hyenas. Nature 308:843-45

232. Owens, M. J., Owens, D. D. 1978. Feeding ecology and its influence on social organization in brown hyaenas (Hyaena brunnea) of the central Kalahari. East Afr. Wildl. J. 16:113-35

233. Packard, J. M., Mech, L. D. 1980. Population regulation in wolves. In Biosocial Mechanisms of Population Regulation, ed. M. N. Cohen, R. S. Malpass, H. G. Klein, pp. 135-50. New Haven: Yale Univ. Press

234. Packer, C., Pusey, A. E. 1982. Cooperation and competition within coalitions of male lions: Kin selection or game theory. Nature 40:740-42

235. Parker, G. R., Maxwell, J. W., Morton, L. D., Smith, G. E. D. 1983. The ecology of the lynx (Lvnx canadensis) on Cape Breton Island. Can. J. Zool. 61:770-86

236. Pearl, M. C., Schulman, S. R. 1983. Techniques for the analysis of social structure in animal societies. Adv. Study Behav. 13:107-46

237. Peters, R. H. 1983. The Ecological Implications of Body Size. Cambridge: Cambridge Univ. Press. $329 \mathrm{pp}$.

238. Peterson, R. O. 1977. Wolf Ecology and Prey Relationships on Isle Royale, Natl. Park. Serv. Monogr. Ser. No. 11. 210 pp.

239. Pienaar, U. D. V. 1969. Predator-prey relationships amongst the larger mammals of the Kruger National Park. Koedoe 122: 108-76

240. Powell, R. A. 1979. Mustelid spacing patterns: Variations on a theme by Mustela. Z. Tierpsychol. 50:153-65

241. Powell, R. A. 1982. The Fisher: Life Historv, Ecologv, and Behavior. Minneapolis; Univ. Minn. Press. 217 pp.

242. Radinsky, L. 1981. Evolution of skull shape in carnivores. I. Representative modern carnivores. Bioi. J. Linn. Soc. 15:369-88

243. Radinsky, L. 1981. Evolution of skull shape in carnivores. 2. Additional modern carnivores. Bioi. J. Linn. Soc. 16:337-55

244. Radinsky, L. 1982. Evolution of skull shape in carnivores. 3. The origin and early radiation of the modern carnivore families. Paleobiologv 8:177-95

245. Ralls, K. 1976. Mammals in which females are larger than males. Q. Rev. Bioi. $51: 245-76$

246. Ralls, K. 1977. Sexual dimorphism in mammals: Avian models and unanswered questions. Am. Nat. 111:917-38

247. Reich, A. 1978. A case of inbreeding in the African wild dog Lycaon pictus in the Kruger National Park. Koedoe 21:119-23

248. Reich, A. 1981. The behavior and ecology of the African wild dog (Lycaon pictus) in the Krueger National Park. PhD thesis. Yale Univ., New Haven, Conn. 
249. Riedman, M. L. 1982. The evolution of alloparental care and adoption in mammals and birds. $Q$. Rev. Bioi. 57:405-35

250. Rieger, I. 1979. A review of the biology of striped hyaenas, Hyaena hyaena (Linne, 1758). Saeugetierkd. Mitt. 2: 81-95

251. Roberts, M. S., Gittleman, J. L. 1984. Ailurusfulgens. Mamm. Species No. 243

252. Rodman, P. S. 1981. Inclusive fitness and group size with a reconsideration of group sizes in lions and wolves.Am. Nat. 118:275-83

253. Roeder, J. J. 1979. Reproduction die la Genette (G. genetta) en captivite. Mammalia 43:531-42

254. Rood, J. P. 1974. Banded mongoose males guard young. Nature 248:176

255. Rood, J.P. 1978. Dwarf mongoose helpers at the den. Z. Tierpsychol. 48:277-87

256. Rood, J.P. 1983. Banded mongoose rescues pack member from eagle. Anim. Behav. 31:1261-62

257. Rood, J. P. 1983. The social system of the dwarf mongoose. See Ref. 84, pp. 454-88

258. Rosenzweig, M. L. 1966. Community structure in sympatric carnivora. J. Mammal. 47:602-12

259. Rowe-Rowe, D. T. 1976. Food of the black-backed jackal in nature conservation and farming areas in Natal. East Afr. Wildl. J. 14:345-48

260. Rowe-Rowe, D. T. 1978. The small carnivores of Natal. Lammergeyer 25: 1-48

261. Rowe-Rowe, D. T. 1982. Home range movements of black-backed jackals in an African montane region. S. Afr. J. Wildl. Res. 12:79-84

262. Rowe-Rowe, D. T. 1983. Black-backed jackal diet in relation to food availability in the Natal Drakensberg. S. Afr. J. Wildl. Res. 13:17-23

263. Rowell, T. 1972. Social Behaviour of Monkeys. Baltimore: Penguin. 203 pp.

264. Rubenstein, D. I. 1978. On predation, competition, and the advantages of group living. Perspect. Ethology 3:205-31

265. Rudnai, J. A. 1973. The Social Life of the Lion. Wallingford, Pa: Washington Square. 122 pp.

266. Russell, J. K. 1983. Timing of reproduction by coatis (Nasua narica) in relation to fluctuations in food resources. In Seasonal Rhythms in a Tropical Forest Ecosystem: Barra Colorado, ed. E. G. Leigh, pp. 413-31. Washington DC: Smithsonian Inst.

267. Russell, J. K. 1983. Altruism in coati bands: Nepotism or reciprocity? In Social Behavior of Female Vertebrates, ed. S. K. Wasser, pp. 263-90. New York: Academic

268. Rutberg, A. T. 1983. The evolution of monogamy in primates. J. Theor. Bioi. 104:93-112

269. Sandegren, F. E., Chu, E. W., Vandevere, J. E. 1973. Maternal behavior in the California sea otter. J. Mammal. 54:668-79

270. Savage, R. J. G. 1977. Evolution in carnivorous mammals. Palaeontology 20: 237-71

271. Scapino, R. 1981. Morphological investigation into functions of the jaw symphysis in carnivorans. J. Morphol. 167:339-75

272. Schaller, G. B. 1967. The Deer and the Tiger. Chicago: Univ. Chicago Press

273. Schaller, G. B. 1972. The Serengeti Lion. Chicago: Univ. Chicago Press. 480 pp.

274. Schaller, G. B., Crawshaw, P. G. 1980. Movement patterns of jaguar. Biotropica 12:161-68

275. Schaller, G. B., Lowther, G. R. 1969. The relevance of carnivore behavior to the study of early hominids. Southwest. J. Anthropol. 25:307-41

276. Schenkel, R. 1966. Play, exploration and territoriality in the wild lion. Symp. Zool. Soc. London 18:11-22

277. Schneider, K. B. 1978. Sex and Age Segregation of Sea Otters, US Dep. Fish \& Game Final Rep.

278. Schoener, T. W. 1969. Models of optimal size for solitary predators. Am. Nat. 103:277-313

279. Schulman, S. R., Rubenstein, D. I. 1983. Kinship, need, and the distribution of altruism. Am. Nat. 121:776-88

280. Seidensticker, J. C., Hornocker, M.G., Wiles, W. V., Messick, J. P. 1973. Mountain lion social organization in the Idaho primitive area. Wildl. Monogr. 35:1-60 
281. Shields, W. M. 1982. Philopatry, Inbreeding, and the Evolution of Sex. Albany: State Univ. NY Press. 245 pp.

282. Shields, W. M. 1983. Genetic considerations in the management of the wolf and other large vertebrates: An alternative view. In Wolves in Canada and Alaska, Can. Wildl. Serv. Rep. Ser. No. 45, ed. L. N. Carbyn, pp. 90--92. Ottawa: Can. Wildl. Serv.

283. Smith, P. K. 1982. Does play matter? Functional and evolutionary aspects of animal and human play. Behav. Brain Sci. 5:139-84

284. Smithers, R. H. N. 1971. The mammals of Botswana. Nat. Mus. Rhodesia No. 4

285. Stains, H. J. 1975. Distribution and taxonomy of the Canidae. See Ref. 97, pp. 3-26

286. Stamps, J. A., Tollestrup, K. 1984. Prospective territorial defense in a territorial species. Am. Nat. 123:99-114

287. Stanley, S. M., van Valkenburg, B., Steneck, R. S. 1983. Coevolution and the fossil record. In Coevolution, ed. D. J. Futuyma, M. Slatkin, pp. 328-49. Sunderland, Mass: Sinauer

287a. Steams, S. C. 1983. The influence of size and phylogeny on patterns of covariation among lifehistory traits in the mammals. Oikos 41:173-87

288. Steams, S.C. 1984. The effects of size and phylogeny on patterns of covariation in the life history traits of lizards and snakes. Am. Nat. 123:56-72

289. Stirling, I., Latour, P. B. 1978. Comparative hunting abilities of polar bear cubs of different ages. Can. J. Zool. 56:1768-72

290. Storm, G. L., Andrews, R. D., Phillips, R. L., Bishop, R. A., Siniff, D. B., Tester, J. R. 1976. Morphology, reproduction, dispersal, and mortality of midwestem red fox populations. Wildl. Monogr. 49:1-82

291. Strickland, M. A., Douglas, C. W., Nowak, M., Hunziger, N. P. 1982. Fisher. See Ref. 54, pp. 58698

292. Strickland, M. A., Douglas, C. W., Novak, M., Hunziger, N. P. 1982. Marten. See Ref. 54, pp. 599612

293. Sunquist, M. E. 1981. The social organization of tigers (Panthera tigris) in Royal Chitawan National Park, Nepal. Smithson. Contrib. Zool. No. 336

294. Sunquist, M. E. 1983. Dispersal of three radiotagged leopards. J. Mammal. 64:337-41

295. Sussman, R. W. 1977. Socialization, social structure, and ecology of two sympatric species of Lemur. In Primate BioSocial Development, ed. S. Chevalier-Skolnikoff, F. E. Poirier, pp. 515-28. New York: Garland

296. Svendsen, G. E. 1982. Weasels. See Ref. 54, pp. 613-28

297. Terborgh, J. 1983. Five New World Primates: A Study in Comparative Ecology. Princeton, NJ: Princeton Univ. Press 260 pp.

298. Thome, B. L. 1981. Genetic consequences of variation in sib maturation schedules. Acta Biotheor. 30:219-27

299. Tinbergen, N. 1951. The Study of Instinct. New York: Oxford Univ. Press

300. Tinbergen, N. 1963. On aims and methods of ethology. Z. Tierpsychol. 20:410-33

301. Todd, A. W., Keith, L. B. 1983. Coyote demography during a snowshoe hare decline in Alberta. J. Wildl. Manage. 47: 394-404

302. Todd, A. W., Keith, L. B., Fischer, C. A. 1981. Population ecology of coyotes during a fluctuation of snowshoe hares. J. Wildl. Manage. 45:629-40

303. van Ballenberghe, Y. 1983. Extraterritorial movements and dispersal of wolves in southcentral Alaska. J. Mammal. 64: 168-71

304. van Schaik, C. P., van Hooff, J. A. R. A. M. 1983. On the ultimate causes of primate social systems. Behaviour 85:91-117 
305. von Schantz, T. 1981. Evolution of group living, and the importance of food and social organization in population regulation. A study on the red fox (Vulpes vulpes). PhD thesis. Lund Univ., Lund, Sweden

306. Vehrencamp, S. L. 1979. The roles of individual, kin, and group selection in the evolution of sociality. In Handbook of Behavioral Neurobiology, ed. P. Marler, J. G. Vanderbergh, 3:351-94. New York: Plenum

307. Viljoen, S., Davis, D. H. S. 1973. Notes on stomach contents analyses of various carnivores in South Africa. Ann. Transvaal Mus. 28:353-63

308. Volf, J. 1965. Trente-deux jeunes de la genette. Mammalia 28:658-59

309. Walters, C. J., Stocker, M., Haber, G. C. 1981. Simulation and optimization models for a wolfungulate system. In Dynamics of Large Mammal Populations, ed. C. W. Fowler, T. D. Smith, pp. 317-37. New York: Wiley

310. Waser, P. M. 1981. Sociality or territorial defense? The influence of resource renewal. Behav. Ecol. Sociobiol. 8:231-37

311. Waser, P.M., Jones, W. T. 1983. Natal philopatry among solitary mammals. Q. Rev. Bioi. 58:355-90

312. Watts, C. R., Stokes, A. W. 1971. The social order of turkeys. Sci. Am. 224:112-18

313. Webster, W. G. 1977. Territoriality and the evolution of brain asymmetry. Ann. NY Acad. Sci. 43:213-21

314. Wells, M. C., Bekoff, M. 1981. An observational study of scent-marking in coyotes, Canis latrans. Anim. Behav. 29:332-50

315. Wells, M. C., Bekoff, M. 1982. Predation by wild coyotes: Behavioral and ecological analyses. J. Mammal. 63:118- 27

316. Wemmer, C. 1977. Comparative ethology of the large-spotted genet (Genetta tigrina) and some related viverrids. Smithson. Contrib. Zool. No. 239

317. West-Eberhard, M. J. 1975. The evolution of social behavior by kin selection. Q. Rev. Bioi. 50:1-34

318. West-Eberhard, M. J. 1979. Sexual selection, social competition, and evolution. Proc. Am. Philos. Soc. 123:222-34

319. Western, D. 1979. Size, life history and ecology in mammals. Afr. J. Ecol. 17:185-204

320. Wiley, R. H. 1981. Social structure and individual ontogenies: Problems of description, mechanism, and evolution. Perspect. Ethology 4:105-33

321. Williams, G. C. 1966. Adaptation and Natural Selection. Princeton, NJ: Princeton Univ. Press. 307 pp.

322. Wilson, D. S. 1975. The adequacy of body size as a niche difference. Am. Nat. 109:769-84

323. Wilson, D. S. 1980. The Natural Selection of Populations and Communities. Menlo Park, Calif.: Benjamin/Cummings. $186 \mathrm{pp}$.

324. Wilson, E. 0. 1975. Sociobiology: The New Synthesis. Cambridge, Mass: Harvard Univ. Press. 697 pp.

325. Wilson, S., Kleiman, D. G. 1974. Eliciting and soliciting play. Am. Zool. 14: 341-70

326. Wittenberger, J. F. 1981. Animal Social Behavior. Boston: Duxbury. 722 pp.

327. Wittenberger, J. F., Tilson, R. L. 1980. The evolution of monogamy: Hypotheses and evidence. Ann. Rev. Ecol. Syst. 11:197-232

328. Wolf, K., Schulman, S. R. 1984. Male response to "stranger" females as a function of female reproductive value among chimpanzees. Am. Nat. 123:163-74

329. Woolpy, J. H., Eckstrand, I. 1979. Wolf pack genetics. A computer simulation with theory. In The Behaviour and Ecology of Wolves, ed. E. Klinghammer, pp. 206-24. New York: Garland

330. Zimen, E. 1976. On the regulation of pack size in wolves. Z. Tierpsychol. 40:300-41

331. Zimen, E., ed. 1980. The Red Fox: Symposium on Behaviour and Ecology. The Hague: Junk. 285 pp.

332. Zimen, E. 1981. The Wolf: A Species in Danger. New York: Delacorte. 373 pp. 